May 2021

\title{
China's Foreign Technology Wish List
} CSET Issue Brief

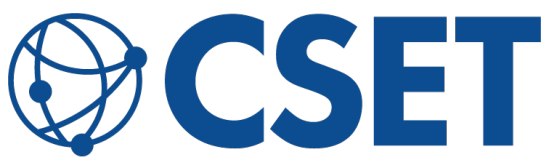

CENTER for SECURITY and EMERGING TECHNOLOGY
AUTHORS

Ryan Fedasiuk

Emily Weinstein

Anna Puglisi 


\section{Executive Summary}

Within the People's Republic of China's broader strategy to acquire foreign technology, “science and technology diplomats” (科技外交 官) act as brokers. Stationed in PRC embassies and consulates across 52 countries, S\&T diplomats monitor host country technological breakthroughs, identify investment opportunities for Chinese firms, and serve as the overseas arm of the International Cooperation Department of China's Ministry of Science and Technology (MOST).

S\&T diplomats occupy a unique role in China's technology acquisition strategy, forming a bridge between foreign and domestic entities. At home, MOST personnel interface with Chinese firms and track the scientific bottlenecks holding back China's development. Abroad, they coordinate with overseas scientists, professional associations, diaspora guilds, and elements of the United Front Work Department in the countries where they are stationed, to identify opportunities where Chinese firms can grow relationships and invest. In short, S\&T diplomats form the outward-facing portion of China's broader technology transfer ecosystem, and monitor scientific breakthroughs, technology enterprises, and other forms of innovation that may be of interest to the Chinese government. ${ }^{1}$

By drawing on the resources and infrastructure of the state, ostensibly private Chinese companies can more easily gain access to technologies abroad. MOST's international outreach efforts have helped Chinese companies sign investment, licensing, and production agreements with foreign tech companies; hire foreign research and development (R\&D) personnel to work in China; and identify cutting-edge research among academia and government laboratories. These accomplishments, in turn, contribute to the PRC's "going out" strategy and goals set forth in state policies including Made in China 2025. ${ }^{2}$

We arrive at this conclusion by examining 642 "international technological cooperation opportunities" (国际技术合作机会) identified by China's S\&T diplomats from 2015 to 2020. Filed by PRC embassy and consulate staff, these reports reflect the Chinese 
government's assessments of more than 300 foreign companies, universities, research institutions, and individuals who are pioneering technology products in a variety of fields-and how likely they would be to partner with Chinese firms, share intellectual property (IP), or establish joint ventures in China. We offer the following observations about the methods by which S\&T diplomats seek technology, the content of the projects that interest them, and the locations and success of their technology acquisition efforts:

- Methods: S\&T diplomats use a variety of state-sponsored methods, including the PRC's expansive foreign influence apparatus, to monitor technology developments overseas. After identifying or cultivating "international technical cooperation opportunities," they often advise Chinese firms to purchase equity, invest specific amounts of money, or strike patent license agreements with foreign companies.

- Content: When vetting potential partners, S\&T diplomats tend to recommend investment positions that advance Chinese equity in supply chains relevant to the Chinese Communist Party's (CCP) stated development objectives. Half of all projects assessed in this report are related to biotechnology or artificial intelligence (AI). PRC diplomats also frequently sought to acquire components and systems currently used by the militaries of the United States and U.S. allies.

- Locations: Nearly half of all technology projects referred by Chinese S\&T diplomats originated in Russia, the United States, the United Kingdom, and Japan. Prior to its closure in July 2020, the PRC consulate in Houston, Texas, referred the most S\&T projects of any Chinese diplomatic post in the world. Still, fewer than 12 percent of projects in our dataset originated in the United States. NATO members and U.S.designated Major Non-NATO Allies hosted more than 70 percent of the S\&T projects targeted by Chinese diplomatic personnel from 2015 to 2020, underscoring the need for U.S. policymakers to coordinate with allies and partners, 
who share the brunt of Chinese technology acquisition efforts.

- Success: Chinese diplomats seem to be successful in acquiring foreign technology. After investigating a limited sample of 30 companies identified as "cooperation opportunities," we find that about half actually establish partnerships with enterprises in China or otherwise expose their IP after S\&T diplomats identify them as potential partners. 


\section{Table of Contents}

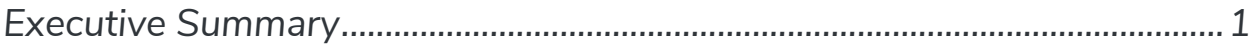

The Role of China's Science and Technology Diplomats .............................. 6

Identifying Needs at Home ....................................................................... 7

Tracking Breakthroughs Abroad .................................................................. 7

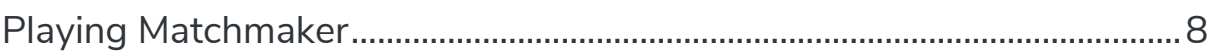

Converting Foreign Science into Domestic Gains.......................................... 9

Compiling China's Wish List: Methodology and Scope .............................. 11

Overall Assessment ........................................................................................ 13

Targeted Technologies Reflect China's Central Development Plans ....... 14

Biotechnology and Pharmaceuticals ........................................................... 15

Artificial Intelligence and Machine Learning ............................................ 16

Technologies with Military Applications ..................................................... 17

Locations and Types of Courted Institutions................................................ 19

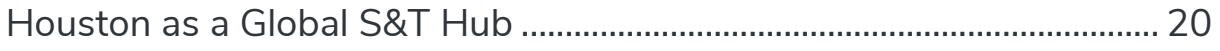

Russia as a Technological Breadbasket.................................................. 21

Government-Sponsored Research ......................................................... 21

Forms of Envisioned Cooperation......................................................................... 23

Case Studies: Does China Get What It Wants? .......................................... 25

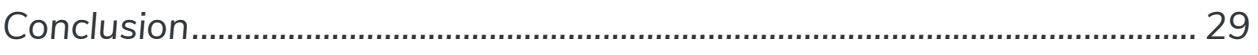

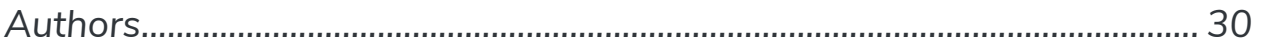

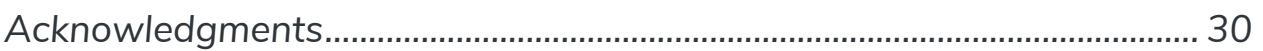

Appendix I: Counting Forms of Envisioned Cooperation ............................ 31

Appendix II: Example “Matchmaking” Partner Search Forms..................... 32

(A) Technology Cooperation Requirements Form ....................................... 32

(C) S\&T Diplomats Local Tour Requirements Form ........................................ 38

Appendix III: Example PRC Consulate Report: Carmell Therapeutics...... 42

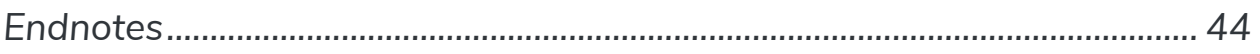




\section{Introduction}

China has pursued a half-century effort to build its S\&T infrastructure. Foreign technology acquisition continues to play a large role in this effort, with commercial technology products becoming increasingly attractive targets. ${ }^{3}$ Numerous books, academic studies, and think tank reports have chronicled how Beijing's "hybrid innovation system" blends forms of academic collaboration, industry partnerships, cyber espionage, direct investment, and influence operations to enhance China's comprehensive national power. ${ }^{4}$ However, while China's S\&T ambitions are well-known, what has been more elusive is how exactly the CCP's strategic goals are carried out in practiceincluding which government personnel broker and support foreign technology acquisition. This is a key piece of the puzzle for U.S. and allied policymakers as they try to balance the importance of openness and transparency with the necessity of protecting against policies that undermine global norms around science and commerce. $^{5}$

This study will outline the scope, mission, and efficacy of China's global science and technology gathering operation, with a focus on the formalized bureaucracy that oversees these efforts. By examining trends in more than six hundred reports filed by the S\&T directorates of PRC embassies and consulates, this report quantifiably assesses the types of technologies the Chinese government is most focused on acquiring and the worldwide locations that are the sources of that technology. Still, it is important to understand China's foreign technology wish list as a signal of intent, not capability. Quantifying the impact of state support for ostensibly private Chinese firms remains challenging, as many of the PRC's technology transfer processes are opaque by design. 


\section{The Role of China's Science and Technology Diplomats}

For more than six decades, the Chinese government and ruling Communist Party have worked to construct a formalized bureaucracy dedicated to absorbing foreign technical information and identifying partners able to provide it. ${ }^{6}$ The International Cooperation Department of China's Ministry of Science and Technology today employs more than 140 "science and technology diplomats" stationed in the S\&T directorates of PRC embassies and consulates worldwide. ${ }^{7}$ Their charge is to monitor developments in global S\&T, and to seek out opportunities for Chinese firms to "make full use of international resources" and "expand channels for international science and technology cooperation." ${ }^{8}$ Put succinctly, China's S\&T diplomats are an extension of the country's industrial policy. They aim to identify the people, products, technologies, and companies that Chinese firms should invest in or acquire to advance China's quest to become an economic and scientific powerhouse.

Figure 1. Countries Hosting Chinese Science and Technology Directorates (2020).

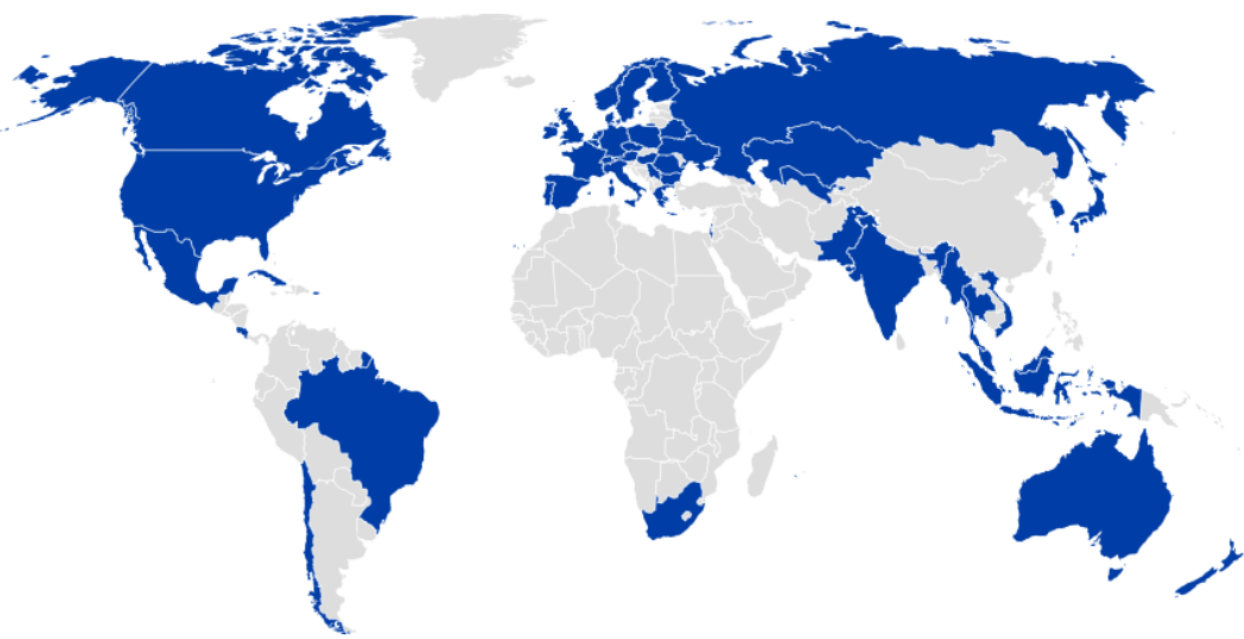

Source: Adapted from International Cooperation Department of the Chinese Ministry of Science and Technology. ${ }^{9}$ 


\section{IDENTIFYING NEEDS AT HOME}

China's S\&T diplomats begin by identifying technology needs at home. They are explicitly tasked with implementing major policies like the Medium- and Long-Term Plan for Science and Technology Development (2006-2020) and Made in China 2025. ${ }^{10}$ MOST solicits and maintains databases of information about the scientific shortfalls of Chinese enterprises and research institutions, and shares that information with S\&T diplomats working abroad. Specifically, MOST asks China-based organizations to fill out "[foreign] partner search forms" specifying the technical achievements that would accelerate their growth-examples of such paperwork can be found in Appendix II of this report. S\&T diplomats also coordinate closely with other CCP and government organizations, including the Science and Technology Commissions of Party Committees in each province, science and technology "innovation parks" (i.e., commercialization enclaves), and "maker spaces" established and supported by the Chinese government.

\section{TRACKING BREAKTHROUGHS ABROAD}

S\&T diplomats leverage overseas Chinese professional associations, Chinese Student and Scholar Associations, and a network of CCP-sponsored organizations known as the "United Front" to gain a nuanced understanding of the state of the art in fields of science, as well as the specific entities and individuals with the skills and information necessary to accelerate China's development. ${ }^{11}$ The United Front carries out a wide array of influence operations aimed at ethnic minority groups inside China, Chinese living abroad, and foreigners. ${ }^{12}$ In the context of China's foreign technology acquisition strategy, elements of the United Front monitor scientific breakthroughs in research communities worldwide, and offer a variety of incentives for foreign and overseas Chinese scientists to share technical information with entities in China. ${ }^{13}$ By making use of "government-organized nongovernmental organizations," the CCP is able to build trust and gain access to people, information, and equipment where an overt 
government or military organization would normally be met with resistance. ${ }^{14}$

Although Chinese diplomats often downplay the role of their overseas influence operations, budget and expenditure documents from CCP committees and offices affiliated with the United Front confirm that they do make payments to overseas scholars, and sometimes pass funding through Chinese universities, obfuscating the role of the CCP and government. ${ }^{15}$ For example, in 2017, the Human Resources and Social Security Bureau of the Hunan Provincial Committee of the CCP made at least $\$ 178,000$ in payments to fund research projects in nine countries, first passing the funds to Chinese universities, which underwrote the payments. ${ }^{16}$ The United Front Work Department in Hunan likewise funds an "overseas friendship association" as a way to advance the CCP's influence overseas, using funds earmarked as "special funding for the introduction of foreign knowledge” (引进国外智力专 项经费) to cosponsor research projects with foreign scientists. ${ }^{17}$ The flow of money from Hunan is just one example of how the Communist Party indirectly and comprehensively extends influence overseas. The United Front engages in indirect funding transfers at both the central and local levels of Chinese governance. By tapping into a vast network of foreign resources, China's S\&T diplomats are able to fill strategic gaps in China's technology industries while obscuring the role of the CCP and government. ${ }^{18}$

\section{PLAYING MATCHMAKER}

Acquiring foreign technology is a central mission of Beijing's public diplomacy and international influence campaign. After identifying foreign partners able to fill the technical gaps of Chinese enterprises, S\&T diplomats coordinate with overseas professional associations and United Front groups to host "matchmaking" events, where Chinese investors engage in "one-on-one negotiations" with foreign businesses looking to enter the Chinese market. ${ }^{19}$ In 2014, for example, a diaspora association in Sweden hosted an event attended by four hundred European businesses, and recommended several dozen technology projects for Chinese firms to invest in. ${ }^{20}$ Dozens, if not hundreds of similar events take 
place each year, including in the United States. ${ }^{21}$ Figure 2, a Chinese-language graphic on the website of the PRC Technology Transfer Center in Italy, illustrates some of the resources and infrastructure that Chinese S\&T diplomats tap into during "matchmaking" and business-to-business (B2B) "project docking" events.

Figure 2. Resources and Infrastructure Available to China's S\&T Diplomats.

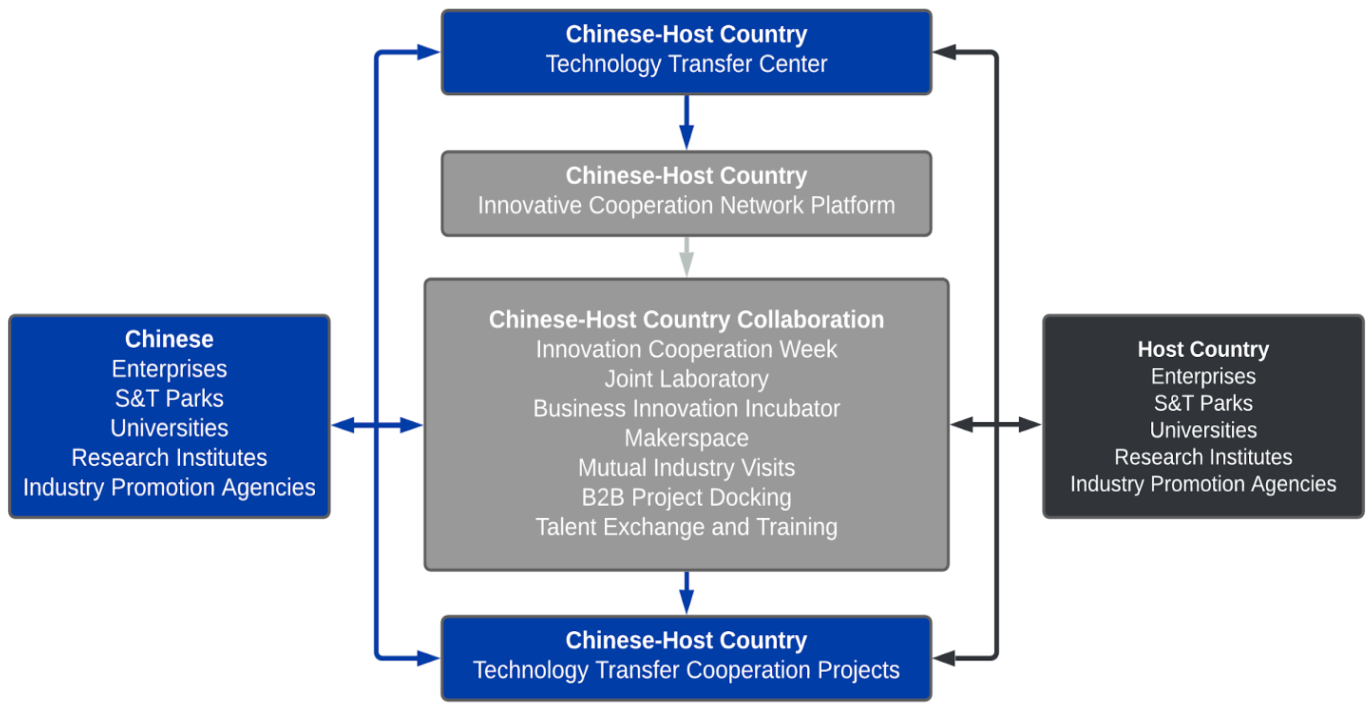

Source: Adapted from China-Italy Technology Transfer Center. ${ }^{22}$

\section{CONVERTING FOREIGN SCIENCE INTO DOMESTIC GAINS}

China's S\&T Conversion Law, originally enacted in 1996 and amended in 2015, aims to accelerate the conversion of S\&T achievements into “actual productive forces" (生产力). The law works in tandem with China's 2015 Innovation-Driven

Development Strategy (创新驱动发展战略) and military-civil fusion (MCF; 军民融合) development strategy to promote the integration of S\&T between China's economic and security apparatuses, thereby improving China's ability to compete economically and militarily with the United States. Article 12 of the S\&T Conversion Law lays out the types of S\&T projects that can be considered for state support, such as those that enhance industrial technology 
levels, and those that enhance national security and public security capabilities. Several types of institutions, including universities, state-owned firms, government-run research institutions, and nonstate-owned enterprises are encouraged to participate in S\&T conversion. State support in this context ranges from participation in S\&T achievement conversion to government guidance funds, ${ }^{23}$ as well as access to loan subsidies, grants, venture capital, incubation opportunities, coaching, and other benefits. Beyond Chinese entities, Article 6 also stipulates that overseas organizations fall under the purview of this law, meaning that their IP and S\&T achievements may be considered fair game for conversion efforts. ${ }^{24}$

All facets of China's S\&T infrastructure are responsible for implementing these policies. For instance, the Chinese Academy of Sciences in 2016 announced the "Key Special Project for the Transfer and Conversion of Scientific and Technological Achievements" (转移转化重点专项项目), otherwise known as the “Hongguang Special Project” (弘光专项). According to CAS, this project is designed to prioritize support for the transfer and conversion of S\&T achievements within CAS. It lays out due diligence and accountability mechanisms, and timelines for the implementation of S\&T conversion projects (around 12-18 months per project). It also lays out the benefits provided to projects under the Hongguang umbrella, such as subsidies, resources, and easier access to collaboration opportunities with other CAS entities. ${ }^{25}$ 


\section{Compiling China's Wish List: Methodology and Scope}

China's S\&T diplomats publish a monthly bulletin of "international technological cooperation opportunities" (国际技术合作机会). Dating back to 2008, the dataset reflects Chinese embassies' assessments of nearly one thousand companies, universities, research institutions, and individuals who are pioneering tech products in a variety of fields-and how likely they would be to partner with Chinese firms, share IP, or establish joint ventures in China. We reviewed information from every "international technical cooperation opportunity" published by MOST from 2015 to 2020. The resulting list comprises 642 science and technology projects pioneered by 335 unique targets in 37 countries.

These documents include all aspects of the technology development cycle and range from basic research ("selectively triggering apoptosis of tumor cell proteins"), to patentable inventions ("implantable chip vaccine technology"), and even end products to be commercialized and sold ("automatic floor cleaning machine"). To better understand the scope and objectives of China's global S\&T gathering operation, we manually sorted these 642 projects into the 10 technology categories specified as industry targets under Made in China 2025: information technology, computerized machines and robots, aerospace, marine equipment and ships, railway transportation, new energy and energy-efficient vehicles, energy equipment, agricultural machines, new materials, and biopharmaceuticals and medical devices. ${ }^{26}$ Projects that did not fit into these categories were marked "other." 27 
Figure 3. Number of Tech Cooperation Opportunities Referred by Chinese S\&T Diplomats (2015-2020).

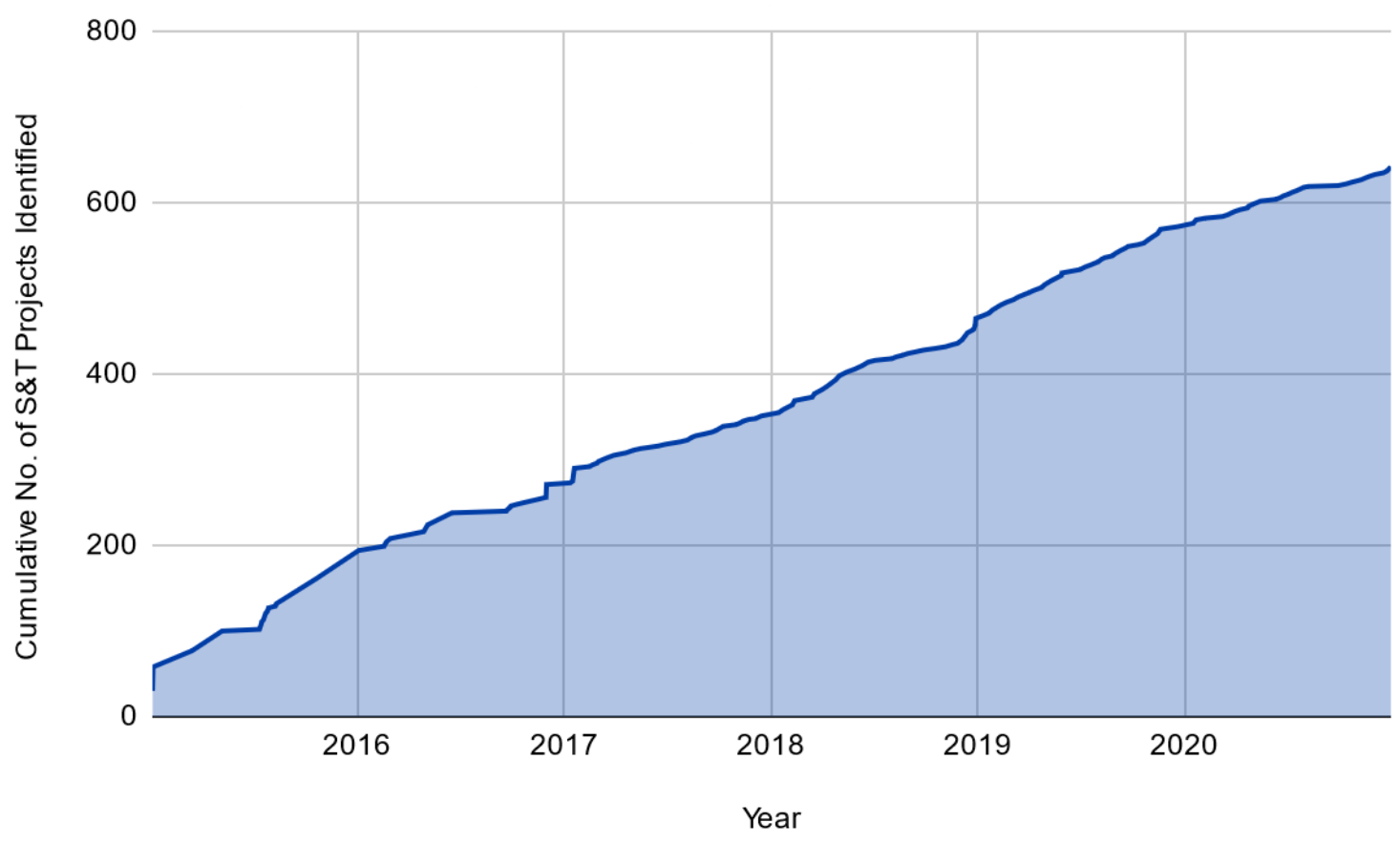

Source: CSET dataset of 642 technology projects identified by Chinese S\&T diplomats. 


\section{Overall Assessment}

China's S\&T diplomats are largely successful in acquiring foreign technical information, some of which may jeopardize U.S. and allied national security and economic competitiveness. After investigating 30 randomly selected companies identified by PRC embassies and consulates, we found that Chinese firms had successfully acquired technologies in 14 cases, either by entering exclusive finance and licensing deals, establishing a joint venture, acquiring the IP in question, or buying the company that developed it. China's S\&T diplomats identify breakthroughs in S\&T not only at the world's leading companies and universities, but also government-run laboratories, nonprofit organizations, law firms, and even by individual researchers. Some of these projects relate to purely commercial goods and services, with few direct military implications-such as vacuum cleaners or wine extractors. But several of the projects we reviewed could improve Chinese security services' military and intelligence gathering operations, if successfully acquired.

We find that Chinese diplomats are leveraging government resources and infrastructure to broker technology investment deals for ostensibly private Chinese companies. The main beneficiaries of MOST's international outreach are the Chinese firms that sign investment, licensing, and production agreements, which in turn contribute to the PRC's "going out" strategy and goals set forth in state policies including Made in China 2025. ${ }^{28}$ 


\section{Targeted Technologies Reflect China's Central Development Plans}

The Chinese government most frequently targets technologies that align with goals set out under major policies like Made in China 2025,29 the Medium- and Long-Term Plan for Science and Technology Development (2006-2020), ${ }^{30}$ and Strategic Emerging Industries Strategy. ${ }^{31}$ Of the projects in our dataset, most related to industries specified in Made in China 2025, including biopharmaceuticals and medical devices (25 percent), information technology (17 percent), or advanced materials (12 percent). Still, we found that nearly one in eight projects referred by China's S\&T diplomats did not fit neatly into any of these industries, but frequently related to other high-priority fields such as water sanitation and air purification. Beyond the Made in China 2025 industries, we observed that the Chinese government was most interested in acquiring technologies related to biotechnology and pharmaceuticals, $\mathrm{Al}$ and machine learning (ML), and projects with potential military applications.

Figure 4. Technologies Targeted by Chinese S\&T Diplomats, by Industry (2015-2020).

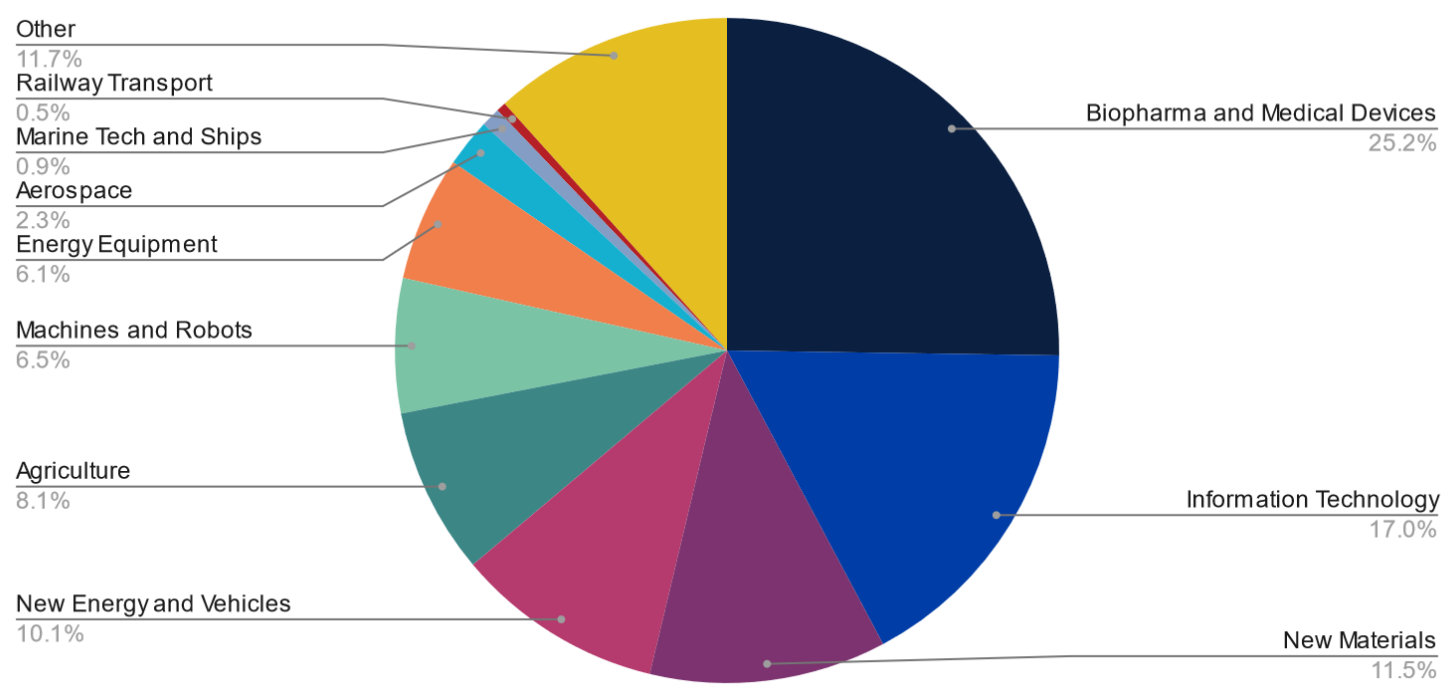

Source: CSET dataset of 642 technology projects identified by Chinese S\&T diplomats. 


\section{BIOTECHNOLOGY AND PHARMACEUTICALS}

China's S\&T diplomats most frequently identified projects related to biotechnology, with 190 projects (25 percent) being related to the "biopharmaceuticals and medical devices" Made in China 2025 industry target. Consistent with prior CSET research findings, we noted that several projects involved brain-inspired research, and several others dealt with cerebrovascular health. ${ }^{32}$ The majority of biotechnology projects identified by PRC embassy and consulate staff originated in Israel, Poland, the United Kingdom, and the United States. Examples include the following:

- In 2015, the Chinese Embassy in Greece noted the pharmaceutical company UniPharma SA was "looking for Chinese partners and distribution agents." Three years later, UniPharma wrote that a Chinese delegation consisting of 11 pharmaceutical companies visited UniPharma's new plant facilities to evaluate potential business opportunities. ${ }^{33}$

- U.S.-based Drylet is a bioremediation technology firm that develops biocatalysts for use in wastewater treatment. In September 2016, the Chinese Consulate in Houston encouraged Chinese firms to seek partnerships with Drylet. ${ }^{34}$ One year later, Drylet announced a partnership between itself and Nanjing Hoyo Municipal Utilities Investment Administration Group that resulted from a delegation of CEOs, led by a former U.S. cabinet official. ${ }^{35}$

- In July 2020, the Chinese Embassy in Israel noted that it wished to cooperate with Israel-based Hospitech Respiration to export their ventilator device, AnapnoGuard. ${ }^{36}$ In November that year, Hospitech Respiration announced the establishment of a joint venture with China's AwakeZone Medical to improve R\&D production of AnapnoGuard in China. AnapnoGuard has already been in use in China since 2018 and has been used to help treat patients with COVID-19. ${ }^{37}$ 


\section{ARTIFICIAL INTELLIGENCE AND MACHINE LEARNING}

We also noted a large number of projects related to Al and ML. Of the 642 project descriptions we analyzed, 171 (27 percent) mentioned keywords related to $\mathrm{Al}$ and $\mathrm{ML}$, implying that $\mathrm{Al}$-related technology projects are near the top of China's foreign technology wish list. ${ }^{38}$ Among the bulletins, we found several companies that produced ML-based video recognition software and unmanned aerial vehicle (UAV) object recognition algorithms, which Chinese embassy and consulate staff judged would be willing to partner with Chinese counterparts. We also found several companies related to integrated circuit design, semiconductor fabrication, and computer-automated design tools. Examples include the following:

- Ukrainian startup Senstone is a voice-to-text company that produces a wearable voice transcriber. Its product uses Al to detect and record emotions in speech. In 2015, the company relocated to Redwood City, California. ${ }^{39}$ In June 2018, the Chinese Consulate in Houston filed a report about Senstone, which noted that the company was seeking \$2 million in foreign-convertible bonds. That summer, Senstone began manufacturing product in Shenzhen, China. Senstone CEO Nazar Fedorchuk later complained that the manufacturing partner had been more costly than anticipated, and delays resulted from quality assurance issues. ${ }^{40}$

- In January 2016, Chinese S\&T diplomats in Belgium recommended establishing partnerships with Belgian Leuven Instruments, a semiconductor equipment supplier. ${ }^{41}$ Eleven months later, Jiangsu Leuven Instruments was jointly established by Belgian Leuven Instruments and the Institute of Microelectronics of the Chinese Academy of Sciences. The joint venture is headquartered in Jiangsu Province and operates an R\&D center and sales department in Belgium. ${ }^{42}$ The CEO of Jiangsu Leuven Instruments, Dr. Kaidong Xu, received his $\mathrm{PhD}$ in Chemistry from the University of Leuven. ${ }^{43}$

- Innoviz Technologies, founded in Israel in 2016, develops and produces LiDAR sensors and perception software for 
mass production of autonomous vehicles. ${ }^{44}$ LiDAR is critical for the development of autonomous vehicles, and the Chinese government labeled LiDAR as a "strategic emerging industry" in 2020. ${ }^{45}$ The Chinese Embassy in Israel recommended that Chinese firms partner with Innoviz to promote their LiDAR products in 2019. ${ }^{46}$ In February 2020, Innoviz announced that it had been selected by Shaanxi Heavy Duty Automobile Co. to provide solid-state LiDAR for an autonomous truck project at a Chinese port. ${ }^{47}$

\section{TECHNOLOGIES WITH MILITARY APPLICATIONS}

China's S\&T diplomats are clearly interested in acquiring projects with potential military applications. We did not code whether each of the 642 projects was militarily relevant; as it is difficult to predict which technologies may become relevant to geopolitical competition and future warfare. But several listed technologies were developed by defense contractors based in the United States and other countries, and PRC embassies and consulates frequently sought to gain equity in companies that produce components or systems currently used by the militaries of the United States and its allies. Examples include the following:

- Aerostar Tactical UAV is an unmanned aerial vehicle produced by Aeronautics Group in Israel. In April 2019, the PRC embassy in Tel Aviv recommended that Chinese firms seek out cooperation opportunities with Aeronautics Group, noting the company has "leading manpower and technology reserves in the field of military and civil aircraft research" and "regards China as the main development market and hopes to cooperate in various fields such as production, marketing, and research and development." 48 The Dutch, Mexican, Polish, and U.S. militaries have each operated the Aerostar UAV. ${ }^{49}$

- ARTEMIS is a cloud-based simulation tool for combat training and emergency response planning. In 2018, the PRC consulate in Calgary, Canada, recommended that Chinese firms cooperate with an unspecified company that 
produces the software. ${ }^{50}$ The report notes that a predecessor to ARTEMIS "is currently the main tool of the U.S. government for disaster relief training," and concludes that "the goal of this project is to localize and customize the training expert system, related technologies, and knowledge to the specific conditions of different provinces and cities in China." 51

- The Institute of Pacific Oceanography of the Far East Branch of the Russian Academy of Sciences has developed a "polarized video system" designed to "evaluate the temporal and spatial characteristics of waves." The project is specifically designed for littoral surveillance and monitoring. The PRC consulate in Vladivostok, Russia, recommended that Chinese firms consider purchasing shares of a new company that may sell the technology, noting that it is especially useful for "assessing the activities of small offshore fleets." 52

Figure 5. Examples of Technologies with Military Applications Targeted by Chinese S\&T Diplomats.

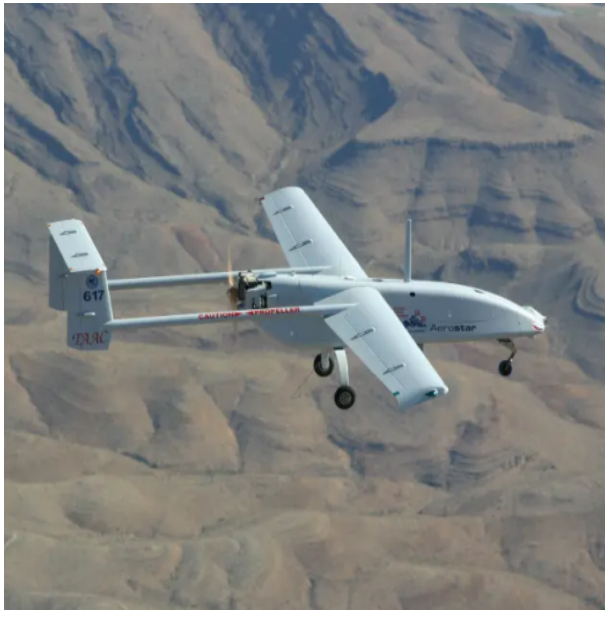

Aerostar Tactical UAS. ${ }^{53}$

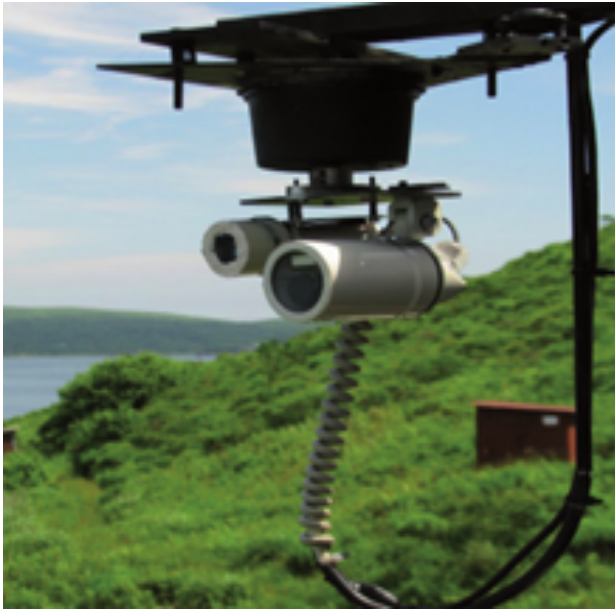

RAS "Polarized Video System." 54 


\section{Locations and Types of Courted Institutions}

China's S\&T diplomats operate out of PRC embassies and consulates located in at least 52 countries, predominantly those in North America, Europe, and East Asia. Unsurprisingly, the Chinese government most often seeks out projects in countries with robust technology sectors and high research output. Nearly half of the technical projects identified by S\&T diplomats originated in Russia (112), the United States (77), the United Kingdom (62), and Japan (57).

Two locations in particular-the PRC consulate in Houston, Texas, and the collection of Chinese diplomatic posts in Russia-stood out for their outsized contributions to the Chinese government's bulletin of overseas S\&T achievements. On net, however, fewer than 12 percent of projects in our dataset originated in the United States, underscoring the need for U.S. policymakers to coordinate with allies and partners, who share the brunt of Chinese technology acquisition efforts. In particular, Chinese S\&T diplomats frequently sought to broker investments in biopharmaceutical and information technology projects based in the United Kingdom, Israel, Canada, and South Korea; and projects related to new materials and clean energy in Japan and Finland. Of the 37 countries that hosted S\&T projects targeted by Chinese S\&T diplomats, 19 are members of NATO or U.S.-designated Major Non-NATO Allies. ${ }^{55}$ U.S. allies hosted more than 70 percent of the S\&T projects targeted by Chinese diplomatic personnel from 2015 to 2020 . 
Figure 6. Most Common Locations of S\&T Projects Identified by Chinese S\&T Diplomats

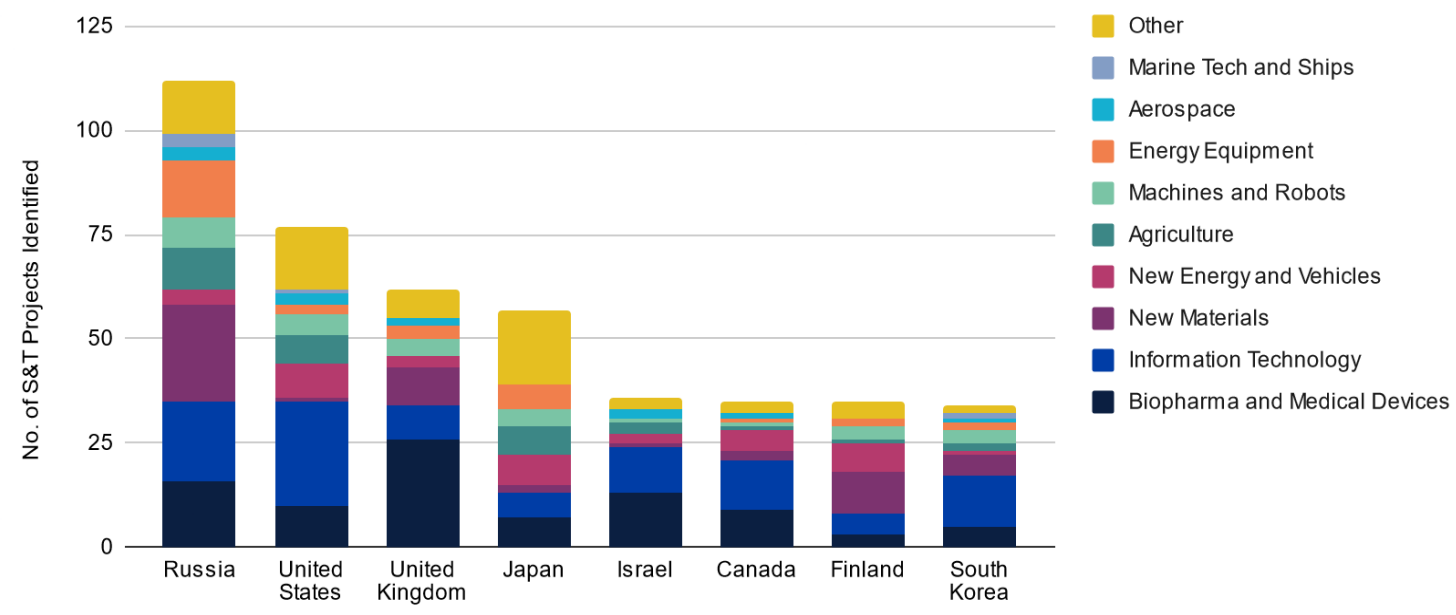

Source: CSET dataset of 642 technology projects identified by Chinese S\&T diplomats (the eight countries listed accounted for 448 projects).

\section{HOUSTON AS A GLOBAL S\&T HUB}

Before its closure in the summer of 2020 , the Chinese Consulate in Houston, Texas was a major hub in China's global S\&T information gathering operation. From January 2015 to July 2020, Houston Consulate staff identified more S\&T projects than any other PRC diplomatic post in the world, and referred 89 percent of the projects originating from the United States. ${ }^{56}$ During that time, the United States was the largest source of information technology projects targeted by Chinese S\&T diplomats. ${ }^{57}$ From 2017 to 2019, the Houston Consulate cosponsored a series of "matchmaking" events with several Chinese technology transfer centers, attracting approximately three hundred U.S. businesses each year. ${ }^{58}$ Since the consulate's closure in July 2020, the MOST bulletin of "international technical cooperation opportunities" has registered only one additional project from the United States, a virtual reality therapy company in Massachusetts. ${ }^{59}$ 


\section{RUSSIA AS A TECHNOLOGICAL BREADBASKET}

Taken collectively, the PRC embassy and consulates in Russia were the top source of "cooperation opportunities" identified by China's S\&T diplomats. PRC diplomatic staff were most interested in earlystage technology projects developed by Russian governmentbacked researchers. Of the 112 projects referred by PRC embassies and consulates in Russia, more than one-third (40) were with researchers working at the Russian Academy of Sciences, primarily at institutes in the Far East Branch. Chinese S\&T

diplomats were particularly interested in acquiring Russian projects related to information technology and advanced materials. Despite their apparent close cooperation, however, the exact nature of Russian-Chinese technical collaboration is unclear. The two countries have signed several agreements pledging to deepen strategic cooperation in S\&T, but based on the actions of China's S\&T diplomats, it seems likely that China views the Russian science community as a breadbasket from which to acquire technology, rather than a partner suitable to jointly pioneer new inventions.

\section{GOVERNMENT-SPONSORED RESEARCH}

Beyond country of origin, it is important for policymakers, researchers, and entrepreneurs to recognize trends in the types of institutions China targets in pursuit of foreign technology. Of the 642 projects in our dataset, 529 reports included details about the institutions that sponsored the technology. We found that Chinese S\&T diplomats overwhelmingly targeted research projects at companies (264 projects; 50 percent) and universities (165 projects; 31 percent). In particular, they were most interested in early-stage companies, and flagged opportunities for Chinese firms to invest during venture rounds of financing. Still, we found that more than 80 research projects ( 15 percent) were conducted at government-sponsored laboratories-including those in Bulgaria, the Czech Republic, Finland, Greece, Italy, Indonesia, Japan, Russia, Singapore, South Korea, Spain, and Sweden. ${ }^{60}$

Among the projects sponsored by government-run labs, 41 percent were related to $\mathrm{Al}, \mathrm{ML}$, or "intelligent" systems and 
equipment. In particular, Chinese diplomats recommended several projects related to unmanned underwater vehicles and autonomous navigation systems at the Institute of Automation and Control Processes within the Russian Academy of Sciences, and at the Korea Electronics and Telecommunications Research Institute.

Figure 7. Types of Institutions Identified as Potential Partners by Chinese S\&T Diplomats

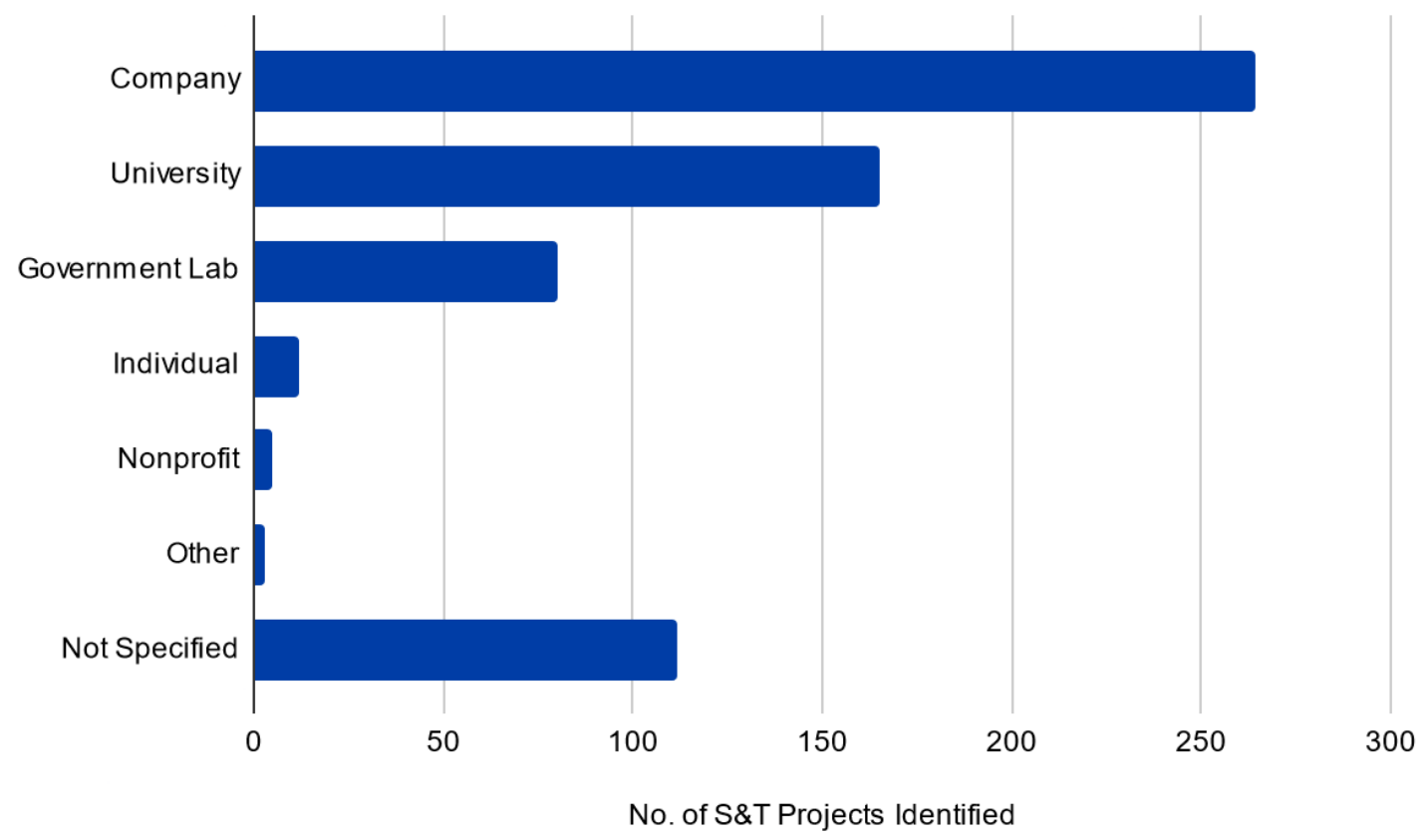

Source: CSET dataset of 642 technology projects identified by Chinese S\&T diplomats (113 did not specify the type of institution being targeted). 


\section{Forms of Envisioned Cooperation}

While the types of suggested cooperation varied on a case by case basis, some patterns emerged from analysis of the projects. Figure 8 below lays out the most common types of collaborations mentioned by Chinese S\&T diplomats_-ranging from broad terms like "cooperative partnerships," to more specific details about amounts of investment, ownership or sharing of equity, the establishment of joint ventures, and others.

Figure 8. Methods of Cooperation Mentioned by Chinese S\&T Diplomats

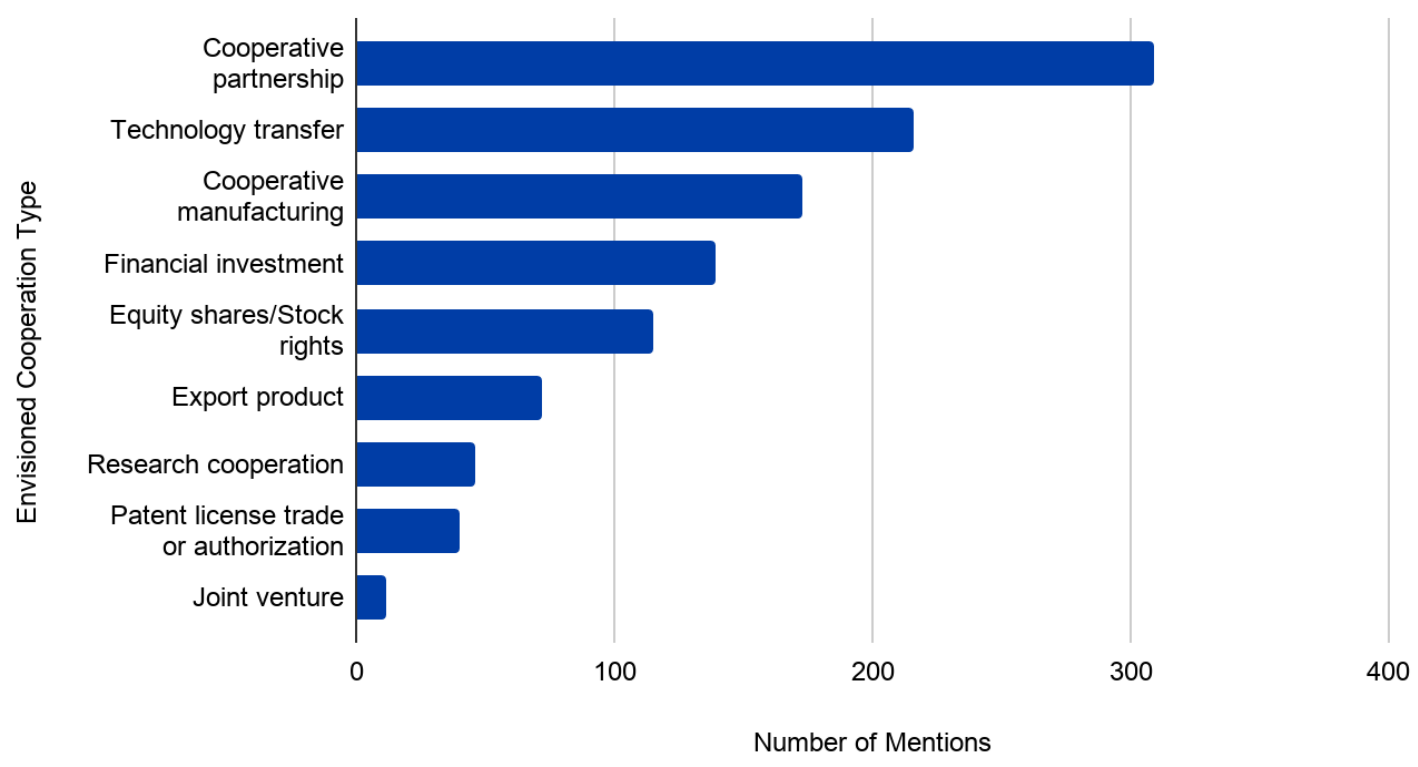

Source: CSET dataset of 642 technology projects identified by Chinese S\&T diplomats. Note: Most reports list more than one method of cooperation.

For example, Chinese S\&T diplomats in 2015 displayed an interest in an unspecified Australian advanced manufacturing firm, stating that the company was "seeking foreign partners for cooperation," suggesting an interest in partnering with Chinese firms. ${ }^{61} \mathrm{In}$ contrast, an S\&T diplomat report from 2016 noted that a specific U.S.-based drilling company was looking for a \$10 million investment from Chinese partners, which suggests a desire for funding from Chinese entities. ${ }^{62}$ 
Joint ventures with ostensibly private Chinese companies are another type of envisioned cooperation. One report from 2018 references Carmell Therapeutics, a U.S. biotechnology firm, and describes the conditions under which the company would set up a joint venture in China. It states that the joint venture firm would be responsible for product certification, production, and clinical trials in China, and that it would exclusively own all of Carmell's IP in China, as well as its technology and sales rights. ${ }^{63}$ U.S. and European firms frequently report being coerced into sharing IP when attempting to do business in China. ${ }^{64}$ Reports from PRC embassies and consulates, such as the Houston Consulate's report on Carmell Therapeutics, reveal that China's S\&T diplomats are central to these processes. An English-language translation of the Houston Consulate report can be found in Appendix III.

Furthermore, multiple types of cooperation may be specified in a given report. For example, a 2016 report on cooperation with the Brno International Clinical Research Center in the Czech Republic states that, beyond a desire for the two sides to conduct collaborative research, the Czech side is potentially willing to promote Chinese medicine and research therapies. ${ }^{65}$ For a more detailed overview of the Chinese terms used for each cooperation type, please see Appendix I. 


\section{Case Studies: Does China Get What It Wants?}

To answer this question, we examined 30 random international technical cooperation opportunities identified by China's S\&T diplomats in 2015 and 2016 to determine whether the companies they targeted had sold equity or established joint ventures or licensing deals with firms in China, or otherwise exposed their IP by attending PRC-sponsored conferences and matchmaking events. ${ }^{66}$ We focused narrowly on technology projects developed by companies because we could not systematically confirm whether researchers at state-backed laboratories or universities were sharing information with Chinese counterparts. Companies, on the other hand, typically produced press releases about investments, licensing deals, mergers, and acquisitions.

Of the 30 cases we investigated, 14 targeted companies indicated that they had actually partnered with a Chinese firm or otherwise exposed their IP to Chinese counterparts, eight did not, and eight lacked sufficient information for us to determine one way or another. ${ }^{67}$ At least two indicated that they also provided products or services to the U.S. military, ${ }^{68}$ and after attending a PRCsponsored matchmaking event in 2016, one went on to receive U.S. Navy funding under the Small Business Innovation Research program. ${ }^{69}$ Table 1 details the timelines surrounding these 14 cases, to illustrate how the technology transfer process works in practice.

Companies on China's foreign technology wish list typically established partnerships with Chinese firms one to three years after S\&T diplomats identified them as potential partners. In a few cases, we noticed S\&T diplomats filed reports after the target announced a partnership with a Chinese firm or attended a PRCsponsored business-to-business matchmaking event. It is not clear whether these projects with reversed timelines were actually the results of PRC diplomats' efforts-and they simply encountered delays in publishing their reports on the internet-or if PRC diplomats were capitalizing on these companies' preexisting relationships with Chinese industry to propose entirely new partnerships. 
Table 1. Firms Targeted by Chinese S\&T Diplomats Typically Share Their Technology.

\begin{tabular}{|c|c|c|}
\hline Company & PRC Diplomatic Report & Indicator of Chinese Partnership \\
\hline $\begin{array}{l}\text { Drylet (United States) sells } \\
\text { products for wastewater } \\
\text { treatment and } \\
\text { bioremediation. }\end{array}$ & $\begin{array}{l}\text { September 29, 2016: S\&T diplomats at } \\
\text { the PRC consulate in Houston filed a } \\
\text { report recommending Chinese firms } \\
\text { cooperate with Drylet. }\end{array}$ & $\begin{array}{l}\text { November 9, 2017: Drylet signs a } \\
\text { strategic cooperation agreement } \\
\text { with the Nanjing Hoyo Municipal } \\
\text { Utilities Investment Administration } \\
\text { Group in Nanjing, China. }{ }^{70}\end{array}$ \\
\hline $\begin{array}{l}\text { EcoTech Group (France) } \\
\text { specializes in } \\
\text { environmental monitoring } \\
\text { technology for smart cities. }\end{array}$ & $\begin{array}{l}\text { March 16, 2015: S\&T diplomats at the } \\
\text { PRC embassy in Paris filed a report } \\
\text { recommending Chinese firms } \\
\text { cooperate with EcoTech Group. }\end{array}$ & 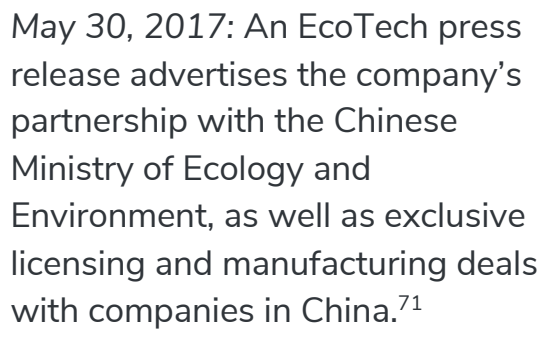 \\
\hline $\begin{array}{l}\text { BioGenerator (Canada) is } \\
\text { an investment } \\
\text { conglomerate composed } \\
\text { of } 12 \text { biotechnology } \\
\text { companies. }\end{array}$ & $\begin{array}{l}\text { January 4, 2016: S\&T diplomats at the } \\
\text { PRC consulate in Toronto filed a report } \\
\text { recommending Chinese firms } \\
\text { cooperate with BioGenerator. }\end{array}$ & $\begin{array}{l}\text { July } 31,2019 \text { : BioGenerator } \\
\text { announces one of its affiliates, } \\
\text { MediBeacon, has entered an } \\
\text { exclusive } \$ 30 \text { million investment } \\
\text { and commercialization partnership } \\
\text { with Huadong Medicine in } \\
\text { Hangzhou, China. }{ }^{72}\end{array}$ \\
\hline $\begin{array}{l}\text { Goodtech (Norway) has } \\
\text { developed a method to } \\
\text { reduce heat leakage } \\
\text { during aluminum } \\
\text { production. }\end{array}$ & $\begin{array}{l}\text { October 21, 2015: S\&T diplomats at } \\
\text { the PRC embassy in Oslo filed a report } \\
\text { recommending Chinese firms invest in } \\
\text { Goodtech. }\end{array}$ & $\begin{array}{l}\text { October 16, 2015: Goodtech is } \\
\text { acquired by Anhui Guozhen } \\
\text { Environmental Protection Energy- } \\
\text { Saving Technology Company, Ltd. } \\
\text { for approximately } \$ 5 \text { million. }{ }^{73}\end{array}$ \\
\hline $\begin{array}{l}\text { RotaChrom (Hungary) is a } \\
\text { pharmaceutical company } \\
\text { focused on drug } \\
\text { purification. }\end{array}$ & $\begin{array}{l}\text { January 4, 2016: S\&T diplomats at the } \\
\text { PRC embassy in Budapest filed a } \\
\text { report recommending Chinese firms } \\
\text { cooperate with RotaChrom. }\end{array}$ & $\begin{array}{l}\text { June 22, 2019: RotaChrom exhibits } \\
\text { at an industry conference in China } \\
\text { and advertises its entry to the } \\
\text { Chinese pharmaceutical market. }^{74}\end{array}$ \\
\hline
\end{tabular}




\begin{tabular}{|c|c|c|}
\hline $\begin{array}{l}\text { Tribosonics (United } \\
\text { Kingdom) produces the } \\
\text { "Ultra Sensor," an } \\
\text { advanced sensor capable } \\
\text { of measuring film } \\
\text { thickness. }\end{array}$ & $\begin{array}{l}\text { January 5, 2015: S\&T diplomats at the } \\
\text { PRC embassy in London filed a report } \\
\text { recommending Chinese firms } \\
\text { cooperate with the University of Bristol } \\
\text { in developing advanced sensors based } \\
\text { on Tribosonics' Ultra Sensor. }\end{array}$ & $\begin{array}{l}\text { July, 2016: The original developer of } \\
\text { the Ultra Sensor, a Tribosonics iOS } \\
\text { software developer named Jiawei } \\
\text { Yao, takes a job as an e-commerce } \\
\text { product manager in Shenzhen, } \\
\text { China. }^{75}\end{array}$ \\
\hline $\begin{array}{l}\text { RUSNANO (Russia) is a } \\
\text { state-backed development } \\
\text { corporation dedicated to } \\
\text { nanotechnology. }\end{array}$ & $\begin{array}{l}\text { December 1, 2016: S\&T diplomats at } \\
\text { the PRC embassy in Moscow filed a } \\
\text { report recommending Chinese firms } \\
\text { cooperate with RUSNANO. }\end{array}$ & $\begin{array}{l}\text { June } 6,2019 \text { : The Russia-China } \\
\text { Investment Fund announces an } \\
\text { investment in Rusalox, a subsidiary } \\
\text { of RUSNANO. }^{76}\end{array}$ \\
\hline $\begin{array}{l}\text { GREENCOMM (South } \\
\text { Korea) produces intelligent } \\
\text { home electronics and } \\
\text { office supplies. }\end{array}$ & $\begin{array}{l}\text { September 23, 2016: S\&T diplomats at } \\
\text { the PRC embassy in Seoul filed a } \\
\text { report recommending Chinese firms } \\
\text { invest in GREENCOMM regarding a } \\
\text { new line of wearable sports } \\
\text { equipment. }\end{array}$ & $\begin{array}{l}\text { December 16, 2016: GREENCOMM } \\
\text { attends the International } \\
\text { Conference on Green Computing } \\
\text { and Communications in Chengdu, } \\
\text { China. }^{77}\end{array}$ \\
\hline $\begin{array}{l}\text { Hanpak Limited (Ireland) } \\
\text { produces the "Butterfly } \\
\text { Cup," a biodegradable } \\
\text { coffee cup. }\end{array}$ & $\begin{array}{l}\text { January 4, 2016: S\&T diplomats at the } \\
\text { PRC embassy in Dublin filed a report } \\
\text { recommending Chinese firms establish } \\
\text { a production agreement with Hanpak. }\end{array}$ & $\begin{array}{l}\text { February 17, 2019: In an interview, } \\
\text { Hanpak CEO Tommy McLoughlin } \\
\text { says the company has licensed the } \\
\text { Butterfly Cup for production in } \\
\text { China. }^{78}\end{array}$ \\
\hline $\begin{array}{l}\text { BlueGreen Water } \\
\text { Technologies Limited } \\
\text { (Israel) is a water } \\
\text { remediation company that } \\
\text { treats algal bloom. }\end{array}$ & $\begin{array}{l}\text { November 30, 2016: S\&T diplomats at } \\
\text { the PRC embassy in Tel Aviv filed a } \\
\text { report recommending that Chinese } \\
\text { firms cooperate with BlueGreen Water } \\
\text { Technologies. }\end{array}$ & $\begin{array}{l}\text { 2018: BlueGreen Water } \\
\text { Technologies enters into a strategic } \\
\text { partnership with China Israel Jizhi } \\
\text { Technology Co., Ltd. }{ }^{79} \text { to clean } \\
\text { Nanhu Lake in Hunan, China. }{ }^{80}\end{array}$ \\
\hline $\begin{array}{l}\text { Oberaigner Group } \\
\text { (Austria) is a heavy } \\
\text { industry supply company } \\
\text { that produces four-wheel } \\
\text { drive vehicles and aircraft. } \\
\text { It also supplies vehicles to }\end{array}$ & $\begin{array}{l}\text { January 4, 2016: S\&T diplomats at the } \\
\text { PRC embassy in Vienna filed a report } \\
\text { recommending Chinese firms } \\
\text { cooperate with Oberaigner Aerospace }\end{array}$ & $\begin{array}{l}\text { September 27, 2012: Oberaigner } \\
\text { unveils the concept of a fiber- } \\
\text { carbon commercial passenger jet at } \\
\text { the } 2012 \text { AOPI Shanghai } \\
\text { International Air Show. Oberaigner } \\
\text { Head of Design Aerospace Juergen }\end{array}$ \\
\hline
\end{tabular}




\begin{tabular}{|c|c|c|}
\hline $\begin{array}{l}\text { the defense forces of the } \\
\text { United Kingdom and other } \\
\text { NATO member states. }{ }^{81}\end{array}$ & $\begin{array}{l}\text { on a new commercial passenger } \\
\text { aircraft. }\end{array}$ & $\begin{array}{l}\text { Schluemer says he sees "big } \\
\text { potential" for the plane in the } \\
\text { Chinese market. }{ }^{82}\end{array}$ \\
\hline $\begin{array}{l}\text { CYBERNET Systems } \\
\text { Corporation (Japan) is a } \\
\text { military research and } \\
\text { development company, } \\
\text { which also contracts with } \\
\text { the U.S. Office of Naval } \\
\text { Research. }\end{array}$ & $\begin{array}{l}\text { May 8, 2015: S\&T diplomats at the } \\
\text { PRC embassy in Tokyo filed a report } \\
\text { recommending that Chinese firms } \\
\text { cooperate to gain access to } \\
\text { CYBERNET's Flat Panel Display } \\
\text { Inspection System (FPiS), a high- } \\
\text { performance sensor. }\end{array}$ & $\begin{array}{l}\text { May 2, 2016: CYBERNET's } \\
\text { subsidiary, Noesis Solutions, opens } \\
\text { a subsidiary branch in Shanghai, } \\
\text { China, and announces it will host an } \\
\text { industry conference "for engineers } \\
\text { from manufacturing companies and } \\
\text { research institutions across } \\
\text { China." }{ }^{44} \text { The company's FPiS sales } \\
\text { increase } 130 \text { percent, year-over- } \\
\text { year, mainly among Chinese } \\
\text { companies. }\end{array}$ \\
\hline $\begin{array}{l}\text { Orbital Traction LLC } \\
\text { (United States) designs } \\
\text { transmission systems for } \\
\text { ship engines. In November } \\
2020 \text {, it completed an } \\
\text { SBIR contract for the U.S. } \\
\text { Navy. }\end{array}$ & $\begin{array}{l}\text { December 1, 2016: S\&T diplomats at } \\
\text { the PRC consulate in Houston filed a } \\
\text { report recommending that Chinese } \\
\text { firms acquire and use Orbital Traction's } \\
\text { engine transmission system. }\end{array}$ & $\begin{array}{l}\text { May 20, 2016: Orbital Traction } \\
\text { COO Chuck Russell seeks to raise } \\
\$ 20 \text { million from Chinese investors } \\
\text { at a PRC-sponsored matchmaking } \\
\text { event in Houston. }{ }^{87}\end{array}$ \\
\hline $\begin{array}{l}\text { DENSO (Japan) produces } \\
\text { mobile cold storage and } \\
\text { preservation vehicles. }\end{array}$ & $\begin{array}{l}\text { March 16, 2015: S\&T diplomats at the } \\
\text { PRC embassy in Tokyo filed a report } \\
\text { recommending Chinese firms } \\
\text { cooperate with DENSO to promote } \\
\text { mobile cold storage solutions. }\end{array}$ & $\begin{array}{l}\text { 2015: DENSO's annual report } \\
\text { states that the company "relocated, } \\
\text { upgraded, and expanded our } \\
\text { technical center in Shanghai" to } \\
\text { facilitate better access the Chinese } \\
\text { market. } 88\end{array}$ \\
\hline
\end{tabular}




\section{Conclusion}

China is making strides toward realizing its dream of technological self-sufficiency and dominating in key technology areas. Chinese companies have caught up to and even surpassed U.S. firms in strategic industries such as 5G, and the country is poised to challenge the United States in a number of fields including genome editing, Al, quantum computing, and aerospace electronics. ${ }^{89} \mathrm{~A}$ key part of this success are Beijing's S\&T diplomats, who are demonstratively effective in gaining access to foreign technology projects and technological know-how.

But for all its success, China's foreign technology wish list is far from complete. S\&T diplomats have been outspoken about the changes they believe China should adopt in its quest for foreign technology. ${ }^{90}$ Some scholars recommend that China take a "diversified development path," which includes acquiring expertise in "aerospace, nuclear energy, new energy, drones, and 5G." 91 The number of PRC diplomatic outposts that host S\&T directorates continues to grow, even as countries like the United States take steps to improve research security. ${ }^{92}$

As China continues to modernize its S\&T infrastructure, the United States and its allies should be clear-eyed about the fundamental differences in the ways Beijing approaches science, technology, and diplomacy. China's S\&T diplomats are one example of how the CCP extends its reach abroad-often in ways that are uncomfortable or alien to foreign governments. By leveraging the resources and infrastructure of the state, ostensibly private Chinese firms can identify investment opportunities more easily and strike deals on better terms than foreign private enterprises. In particular, MOST's mission to service private Chinese companies-and its use of diplomatic resources and state-run information gathering operations to advance that objective-differentiate it from the technology scouting efforts of most other countries. Moving forward, firms looking to do business in China will likely continue to deal with coercive technology transfer, and foreign companies may find it difficult to remain competitive with Chinese firms that benefit from state-backed technology brokers. 


\section{Authors}

Ryan Fedasiuk is a research analyst at CSET and an M.A. candidate at Georgetown University's Security Studies Program. His work explores military applications of artificial intelligence, as well as China's efforts to acquire foreign technical information. Emily Weinstein is a research analyst at CSET. Her work focuses on Chinese innovation and domestic S\&T policies and development, particularly military-civil fusion. Anna Puglisi is a senior fellow at CSET. She previously served as the national counterintelligence officer for East Asia, and is a contributing author to China's Quest for Foreign Technology: Beyond Espionage (Routledge, 2020) and coauthor of Chinese Industrial Espionage (Routledge, 2013).

\section{Acknowledgments}

The authors are grateful to Catherine Aiken, Huey-Meei Chang, Shelton Fitch, William Hannas, Andrew Imbrie, Igor MikolicTorreira, Dewey Murdick, and Lynne Weil for their suggestions on style and content. They are especially grateful to Charles Durant, Katherine Koleski, and Andrew Spear for their comprehensive reviews; and to Ben Murphy, who translated essential documents, including those found in the appendices of this report.

\section{(c) $(9)$}

(C) 2021 by the Center for Security and Emerging Technology. This work is licensed under a Creative Commons Attribution-Non Commercial 4.0 International License.

To view a copy of this license, visit https://creativecommons.org/licenses/by-nc/4.0/. 


\section{Appendix I: Counting Forms of Envisioned Cooperation}

The following terms were extracted from S\&T diplomat reports in order to gain a better understanding of the types of cooperation initiatives that China envisioned for the identified targets. Terms were grouped according to common cooperation themes observed by the authors.

\begin{tabular}{|c|c|}
\hline Cooperation Type (Chinese) & Cooperation Type (English) \\
\hline $\begin{array}{l}\text { 合作伙伴/开展合作/寻找伙伴合作/ } \\
\text { 寻求中国伙伴/伙伴开展合作/技术合作 }\end{array}$ & Cooperative partnership \\
\hline 技术转让/转让技术/技术转移 & Technology transfer \\
\hline 合作生产 & Cooperative manufacturing \\
\hline 融资/风险投资/投资 & Financial investment \\
\hline 股权/技术入股 & Equity shares/Stock rights \\
\hline 出口产品 & Export product \\
\hline 研发合作/合作研究 & Research cooperation \\
\hline 专利许可证贸易/专利授权 & $\begin{array}{c}\text { Patent license trade or } \\
\text { authorization }\end{array}$ \\
\hline 合资 & Joint venture \\
\hline
\end{tabular}




\section{Appendix II: Example "Matchmaking" Partner Search}

\section{Forms}

The following documents are examples of "matchmaking" partner search forms, which Chinese firms are asked to fill out and submit to S\&T diplomats; and internal MOST paperwork filled out by S\&T diplomats. These documents were translated by Etcetera Language Group, Inc., and edited by CSET Chinese STEM Translation Lead Ben Murphy.

\section{S\&T Diplomat Service Action International Cooperation Requirements Tables}

\section{(A) Technology Cooperation Requirements Form}

Province (Region, Municipality): Date:

Postcode

State-owned and state-controlled enterprise

Private enterprise

Sino-foreign joint venture

$\square$ Hong Kong, Macau, and Taiwan-invested enterprise

$\square$ Wholly foreign-owned enterprise

$\square$ Other enterprise (please explain)

\begin{tabular}{|c|c|c|c|}
\hline \multirow{5}{*}{$\begin{array}{l}\text { Project unit } \\
\text { information }\end{array}$} & $\begin{array}{l}\text { Organization } \\
\text { (单位) Name }\end{array}$ & Chinese: & \multirow{2}{*}{ Official seal } \\
\hline & & English: & \\
\hline & Address & Chinese: & English: \\
\hline & Enterprise Type & & \\
\hline & \begin{tabular}{|l} 
Higher-level \\
governing unit
\end{tabular} & (May be left blank by non-state-owned entities & \\
\hline
\end{tabular}




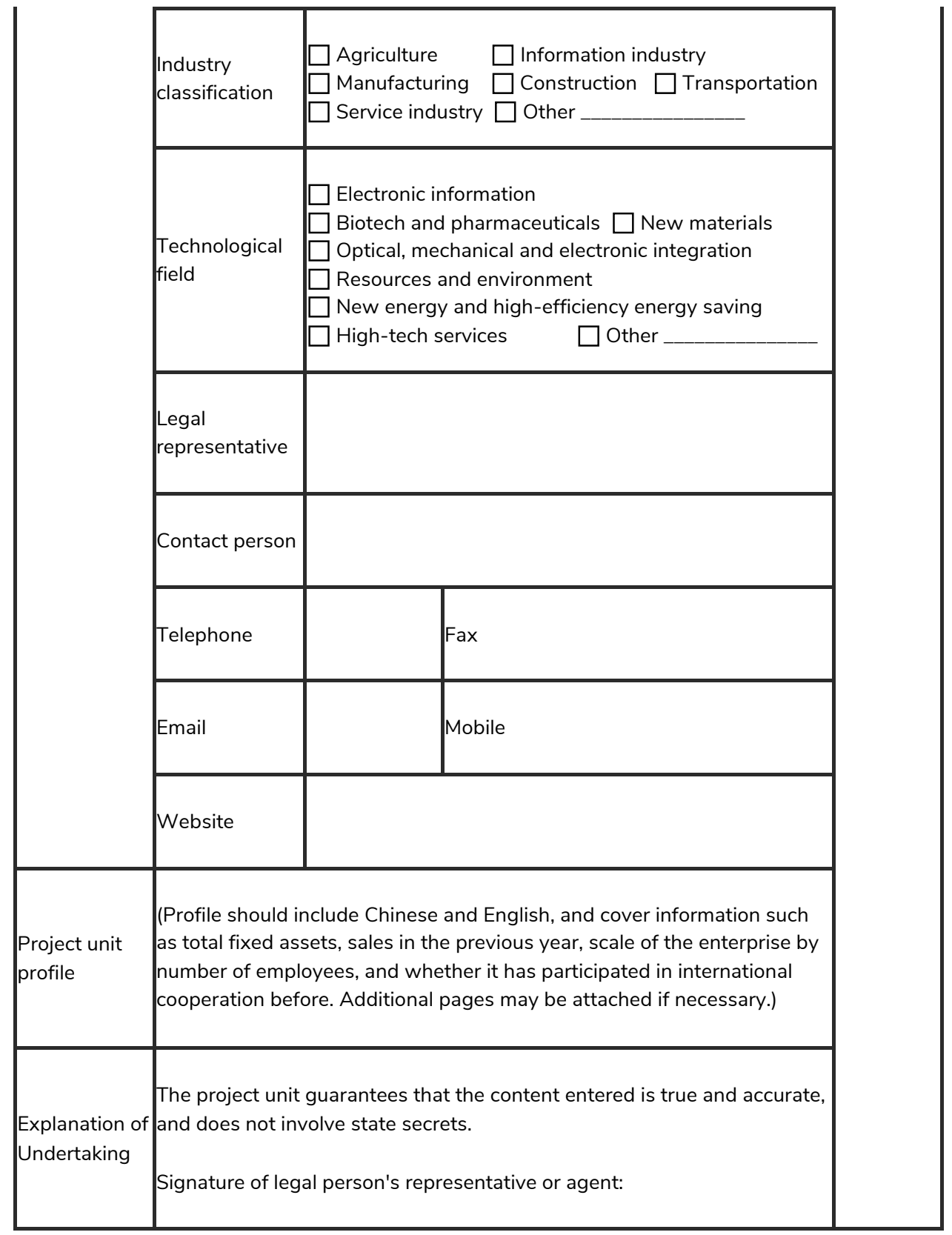

\begin{tabular}{|l|l|}
\hline \multirow{2}{*}{$\begin{array}{l}\text { Name of } \\
\text { project }\end{array}$} & Chinese: \\
\cline { 2 - 2 } & English: \\
\hline
\end{tabular}




\begin{tabular}{|c|c|}
\hline Region & $\begin{array}{l}\square \text { Electronic information } \square \text { Biotech and pharmaceuticals } \\
\square \text { New materials } \\
\square \text { Optical, mechanical and electronic integration } \\
\square \text { Resources and environment } \\
\square \text { New energy and high-efficiency energy saving } \\
\square \text { High-tech services } \quad \square \text { Other }\end{array}$ \\
\hline $\begin{array}{l}\text { Type of } \\
\text { project } \\
\text { cooperation }\end{array}$ & \begin{tabular}{|ll}
$\square$ Foreign mature technology & $\square$ Pre-industrialization phase technology \\
$\square$ Laboratory results & $\square$ Other
\end{tabular} \\
\hline $\begin{array}{l}\text { Technology } \\
\text { sensitivity }\end{array}$ & $\begin{array}{l}\text { Is the needed technology one for which the other party is subject to export } \\
\text { restrictions? } \\
\square \text { Yes } \square \text { No }\end{array}$ \\
\hline $\begin{array}{l}\text { Degree to } \\
\text { which } \\
\text { technology } \\
\text { is advanced }\end{array}$ & \begin{tabular}{|l}
$\square$ Internationally leading \\
$\square$ Internationally advanced \\
$\square$ Domestically leading
\end{tabular} \\
\hline $\begin{array}{l}\text { Main } \\
\text { technical } \\
\text { indicator } \\
\text { requirement }\end{array}$ & \\
\hline $\begin{array}{l}\text { Technology } \\
\text { patent } \\
\text { status }\end{array}$ & $\square$ No patent $\square$ Overseas patent $\square$ Domestic patent \\
\hline $\begin{array}{l}\text { Unique } \\
\text { resources } \\
\text { introduced }\end{array}$ & $\square$ Species $\square$ Samples $\square$ \\
\hline $\begin{array}{l}\text { Effective } \\
\text { period of the } \\
\text { need }\end{array}$ & $\square$ Six months $\square$ One year $\square$ Long-term \\
\hline $\begin{array}{l}\text { Description } \\
\text { of } \\
\text { cooperation } \\
\text { needs: }\end{array}$ & Please describe in detail: (Chinese, English) \\
\hline
\end{tabular}




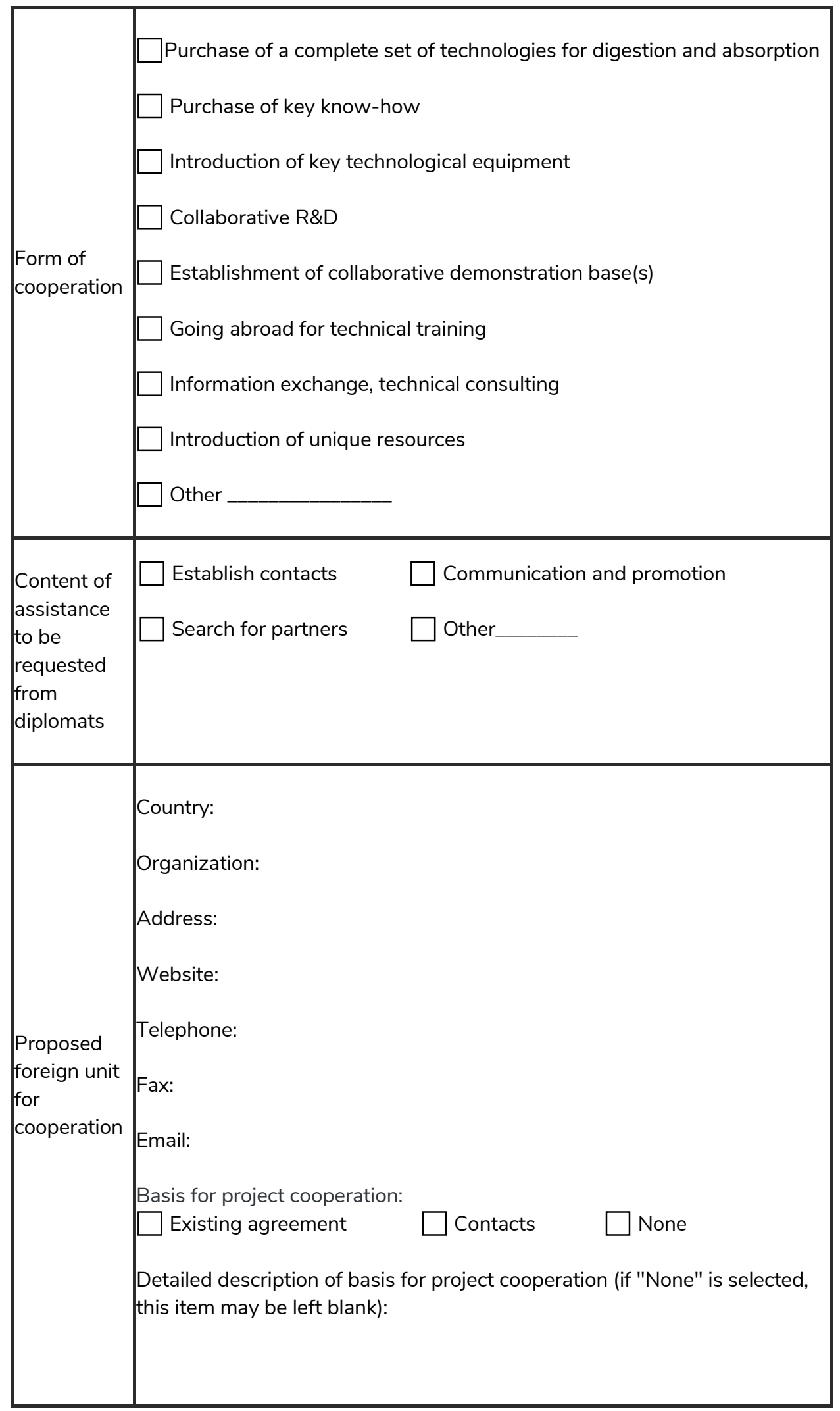




\section{(B) High-end Project Talent Recruitment Requirements}

Province (Region, Municipality): Date:

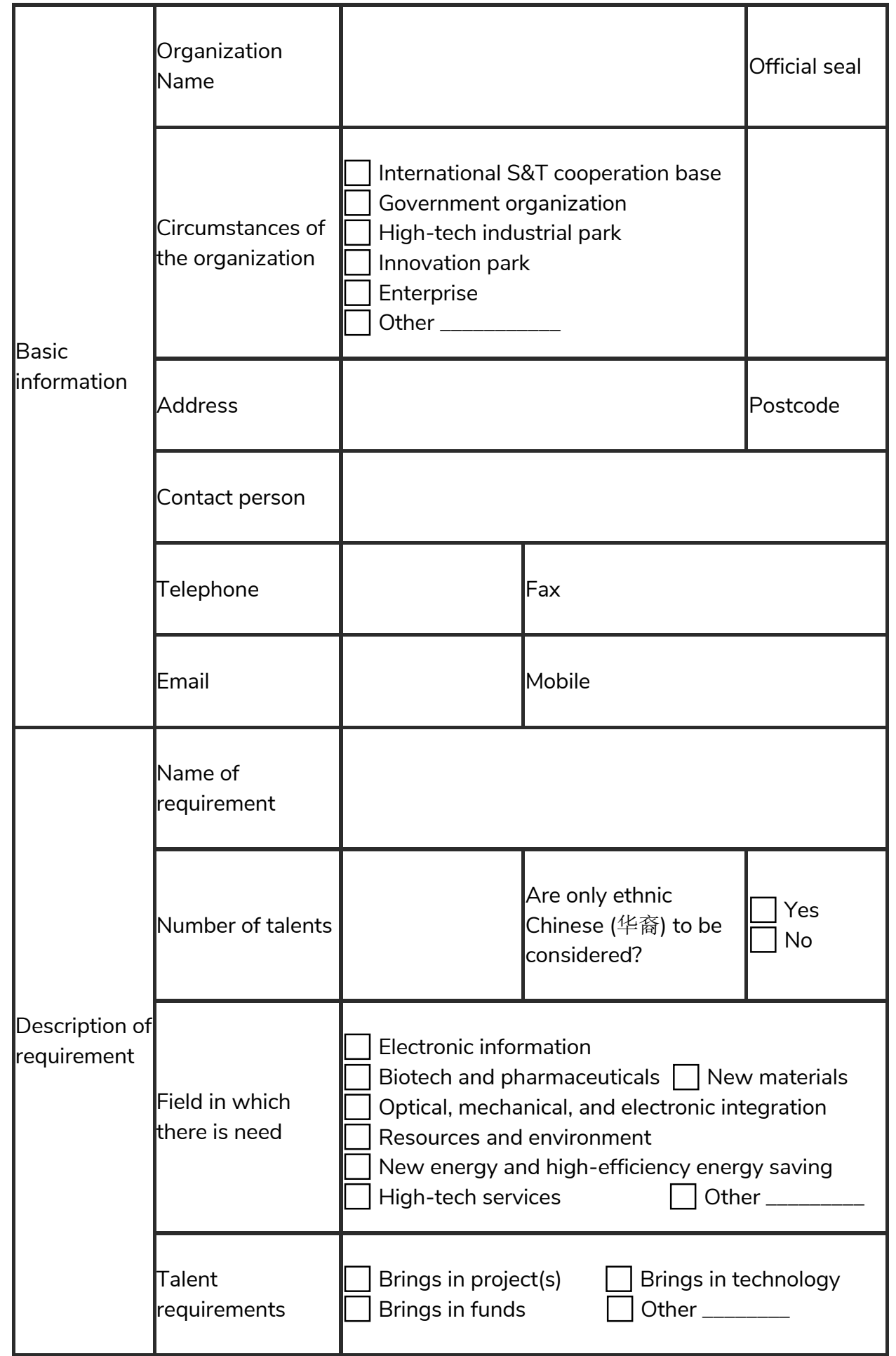




\begin{tabular}{|c|c|c|}
\hline & $\begin{array}{l}\text { To be recruited as } \\
\text { a team? }\end{array}$ & $\square$ Yes $\square$ No \\
\hline & $\begin{array}{l}\text { Recruitment } \\
\text { method }\end{array}$ & $\begin{array}{l}\square \text { Enterprise establishment or leadership } \\
\square \text { Part-time lecturing } \\
\square \text { Scientific research and technology cooperation } \\
\square \text { Investment using technology in exchange for } \\
\text { shares } \\
\square \text { Consulting } \\
\square \text { Other (please explain) }\end{array}$ \\
\hline & Work duration & $\square$ Six months $\square$ One year $\square$ Long-term \\
\hline & $\begin{array}{l}\text { Specific } \\
\text { description (in } \\
\text { conjunction with } \\
\text { corresponding } \\
\text { project) }\end{array}$ & \\
\hline $\begin{array}{l}\text { Overview of } \\
\text { relevant } \\
\text { supporting } \\
\text { policies }\end{array}$ & & \\
\hline
\end{tabular}




\section{(C) S\&T Diplomats Local Tour Requirements Form}

Province (Region, Municipality): Date:

$\square$ Participation in forum $\square$ Special topic report $\square$ Field investigation

Discussion and exchange $\square$ Other

$\square$ Introduce the host country's technology cooperation policies, environment and channels;

$\square$ Introduce the S\&T cutting edge, S\&T strengths and S\&T information of the host country;

$\square$ Carry out exchanges with government and enterprises, provide consulting on actual local needs:

Other

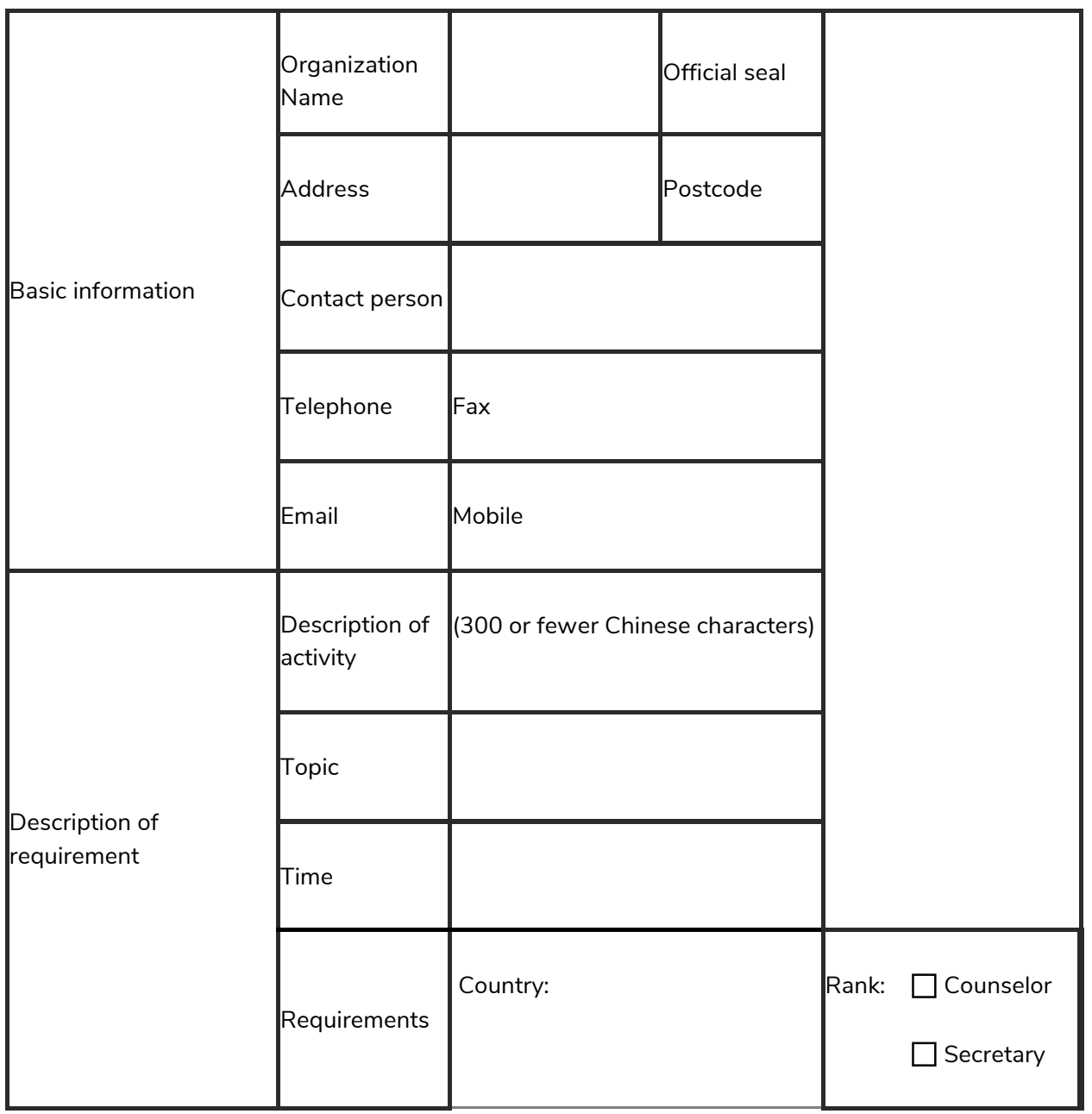




\begin{tabular}{|l|l|l|l|}
\hline & & & Number of people: \\
\cline { 2 - 2 } & Form & & \\
\cline { 2 - 3 } & Content & \\
\hline & $\square$ Settlement of international round-trip tickets & \\
Facilitative support \\
(multiple selections \\
allowed) & $\square$ Settlement of domestic round-trip tickets & \\
& $\square$ Provision of local meals and accommodations & \\
& $\square$ Other _. & \\
\hline
\end{tabular}




\section{(D) Exhibition Contact Schedule}

Province (Region, Municipality): Date:

\begin{tabular}{|c|c|c|c|c|}
\hline \multirow{5}{*}{ Basic information } & $\begin{array}{l}\text { Organization } \\
\text { Name }\end{array}$ & & & Official seal \\
\hline & Address & & & Postcode \\
\hline & Contact person & & & \\
\hline & Telephone & & Fax & \\
\hline & Email & & Mobile & \\
\hline \multirow{5}{*}{$\begin{array}{l}\text { Description of } \\
\text { requirements }\end{array}$} & Type of activity & \multicolumn{2}{|c|}{$\square$ Exhibition $\square$ Forum } & $\square$ Meeting $\square$ Other \\
\hline & $\begin{array}{l}\text { Name of } \\
\text { activity }\end{array}$ & \multicolumn{3}{|l|}{$\begin{array}{l}\text { Chinese: } \\
\text { English: }\end{array}$} \\
\hline & Time & & & \\
\hline & $\begin{array}{l}\text { Description of } \\
\text { main activities }\end{array}$ & \multicolumn{3}{|c|}{$\begin{array}{l}\text { Include: size, level, main content, and other } \\
\text { information (Chinese, English) }\end{array}$} \\
\hline & $\begin{array}{l}\text { Content of } \\
\text { assistance to } \\
\text { be requested } \\
\text { from diplomats } \\
\text { (multiple } \\
\text { selections } \\
\text { allowed) }\end{array}$ & \multicolumn{3}{|c|}{$\begin{array}{l}\square \text { A. Publicity } \\
\square \text { B. Promotion } \\
\square \text { C. Invitation of experts } \\
\square \text { D. Invitation of overseas scientific research } \\
\text { institutions } \\
\square \text { E. Invitation of overseas enterprises } \\
\square \text { F. Invitation of officials of other countries } \\
\square \text { G. Other }\end{array}$} \\
\hline & Country & & Number & \\
\hline
\end{tabular}




\begin{tabular}{|l|l|l|}
\hline $\begin{array}{l}\text { Specific } \\
\text { requirements }\end{array}$ & Field & \\
\cline { 2 - 3 } & $\begin{array}{l}\text { Description of } \\
\text { main work }\end{array}$ & (Chinese, English) \\
\hline \multirow{3}{*}{$\begin{array}{l}\text { Facilitative } \\
\text { support (multiple } \\
\text { selections } \\
\text { allowed) }\end{array}$} & $\square$ Settlement of international round-trip tickets \\
& $\square$ Settlement of domestic landing fees \\
& $\square$ Borne oneself local expenses \\
& $\square$ Settled by negotiation \\
& $\square$ Other \\
\hline
\end{tabular}


Appendix III: Example PRC Consulate Report: Carmell Therapeutics

The following translation comes from the China International Science and Technology Cooperation (CISTC; 中国国际科技合作网) website in 2018. The PRC Ministry of Science and Technology (MOST; 科技部) runs the CISTC website. This particular document appears in the "S\&T Diplomat Service Action Special Topics" (科技 外交官服务行动专题) section of the CISTC website. The document's file number, "2018-35-Houston-5" (2018-35-休斯顿5), indicates that S\&T diplomats working out of the Chinese Consulate General in Houston, Texas identified this cooperation opportunity in 2018. This document was translated by Etcetera Language Group, Inc., and edited by CSET Chinese STEM Translation Lead Ben Murphy.

\section{Carmell C Round (Financing)}

\section{Carmell C轮（融资）}

Carmell is a biotechnology company dedicated to the development and commercialization of regenerative medicine technology. As a spin-off company of Carnegie Mellon University in Pittsburgh, Pennsylvania, Carmell Therapeutics has developed a unique and highly innovative patented technology that uses human plasma to make a kind of biologically active material. The plasma-based bioactive materials (PBMs) contain a certain concentration of natural regeneration factors, which can promote healing in various clinical environments, reduce infections, and reduce the probability of complications, thereby lowering medical costs.

Different from the previous method of providing auxin through wounds/surgery, Carmell's patented technology has made major breakthroughs in form, life span, and biological activity: 1) Regenerated materials can be made into various forms, such as putty, pastes, stents, plugs, screws, and sheets. 2) Its state of existence can be cross-linked with protein as part of the manufacturing process, and it can be broken down in the body across different periods (days, weeks, or months). 3) When the regenerative PBM is biodegraded locally, the active biological 
ingredients can be released where the body needs it and at a specific time to accelerate healing.

Early clinical verification shows that Carmell's first product is effective, safe, affordable, and lasting. Carmell has successfully completed Phase II research, which shows that compared with standard care, this technology can better promote bone healing, wound healing, and reduce infection. A large number of animal studies have proven the role of regenerative PBMs.

In addition, human research data also shows that this technology can deliver biologically active substances to wounds within a period of time. Carmell's initial goal is to solve the key unsolved problem related to orthopedic trauma (open reduction surgery), which is to deliver a biologically active putty-like substance to accelerate healing and reduce infection rates and treatment costs. Carmell's long-term goal is to become an outstanding biotechnology regeneration platform. It is committed to optimizing the rehabilitation process in the medical field to meet various needs in the healing process, such as improving various types of healing, such as bone healing and healing related to spinal fusion, joint replacement, and knee joint repair, accelerating healing, and reducing surgical wound infections. From a long-term perspective, the company can improve the healing of chronic wounds.

Carmell recently held a very successful meeting with the U.S. Food and Drug Administration where the FDA approved Carmell for Phase III clinical studies in order to complete the regulatory approval process. Next, the company will begin clinical trials in the first quarter of 2018, begin one-year recruitment and one-year follow-up visits, and then submit an application to obtain approval for commercial sales qualifications. FDA approval is expected by 2021.

The technology is patented, and the foreign party is seeking a Series $C$ investment of $\$ 20$ million. Meanwhile, the foreign party is also seeking to establish a joint venture in China as a "new company." This company would be responsible for product certification, production, and clinical trials in China. The joint venture would exclusively own all Carmell's intellectual property (in China), technology, and sales rights. 


\section{Endnotes}

${ }^{1}$ William Hannas and Huey-meei Chang, "China's Access to Foreign Al Technology: An Assessment" (Center for Security and Emerging Technology, September 2019), https://cset.georgetown.edu/research/chinas-access-toforeign-ai-technologyl.

${ }^{2}$ Tai Ming Cheung et al., "Planning for Innovation: Understanding China's Plans for Technological, Energy, Industrial, and Defense Development" (Institute on Global Conflict and Cooperation, July 28, 2016), https://www.uscc.gov/sites/default/files/Research/Planning\%20for\%20lnnovatio n\%20\%20Understanding\%20China's\%20Plans\%20for\%20Tech\%20Energy\%20Indu strial\%20and\%20Defense\%20Development072816.pdf.

${ }^{3}$ Anna Puglisi, "The Myth of the Stateless Global Society," in William C. Hannas and Didi Kirsten Tatlow, Beyond Espionage: China's Quest for Foreign Technology (Milton Park: Routledge, 2020): p. 80.

${ }^{4}$ Puglisi, "The Myth of the Stateless Global Society," 80. See also Ted Fishman, China, Inc.: How the Rise of the Next Superpower Challenges America and the World (New York: Simon \& Schuster, 2005); "Made in China 2025: Global Ambitions Built on Local Protections" (U.S. Chamber of Commerce, 2017), https://www.uschamber.com/sites/default/files/final_made_in_china_2025_repor t_full.pdf; and Michael Brown and Pavneet Singh, "China's Technology Transfer Strategy: How Chinese Investments in Emerging Technology Enable A Strategic Competitor to Access the Crown Jewels of U.S. Innovation" (Defense Innovation Unit Experimental, January 2018), https://admin.govexec.com/media/diux_chinatechnologytransferstudy_jan_2018 (1).pdf.

${ }^{5}$ William Hannas, James Mulvenon, and Anna Puglisi, Chinese Industrial Espionage: Technology Acquisition and Military Modernisation, (Milton Park: Routledge, 2013); and "China's Innovation Ecosystem" (World Economic Forum, 2016), http://www3.weforum.org/docs/WEF_GAC_On_China_Innovation_WhitePaper_ 2016.pdf.

${ }^{6}$ William Hannas and Huey-Meei Chang, "China's STI Operations" (Center for Security and Emerging Technology, January 2021),

https://cset.georgetown.edu/research/chinas-sti-operations/.

${ }^{7}$ Sun Degang and Wu Tongyu, "The Fourth Industrial Revolution and China's Science and Technology Diplomacy to Arab Countries” [第四次工业革命与中国对 阿拉伯国家的科技外交], West Asia and Africa Journal [西亚非洲], June 2020, https://web.archive.org/web/20210121230625/http://www.xyfzqk.org/UploadFil e/lssue/tddo3gaw.pdf. 
8 “Science and Technology Diplomat Service Operation Topics” [科技外交官服务 行动专题],

https://web.archive.org/web/20201113202532/http://www.cistc.gov.cn/Diploma cies_Service/.

9 “Scientific and Technological Institutions Stationed Abroad” [驻外科技机构], Ministry of Science and Technology of China, March 8, 2019, https://web.archive.org/web/20200915194710/http://most.cn/zzjg/zwkjjg/index. $\underline{\mathrm{htm}}$.

10 “Science and Technology Diplomat Service Operations" [科技外交官服务行动], Tianjin Foreign Science and Technology Exchange Center [天津市对外科学技术 交流中心], https://web.archive.org/web/20210121222238/http://international.tten.cn/zt/kjw ig/; Nicholas Eftimiades, A Series on Chinese Espionage: Vol. I Operations and Tactics (London: Vitruvian Press, 2020).

${ }^{11}$ The purpose of the United Front is to advance the CCP's influence abroad by forging inroads to industry and civil society. For more information, see Alex Joske, "The Party Speaks for You" (Australian Strategic Policy Institute, June 9, 2020), https://www.aspi.org.au/report/party-speaks-you; and Ryan Fedasiuk, "Putting Money in the Party's Mouth: How China Mobilizes Funding for United Front Work," China Brief 20, no. 16 (September 16, 2020): 35-42, https://jamestown.org/program/putting-money-in-the-partys-mouth-howchina-mobilizes-funding-for-united-front-work/.

${ }^{12}$ See Anne-Marie Brady, "Magic Weapons: China's political influence activities under Xi Jinping," Wilson Center, September 18, 2017, https://www.wilsoncenter.org/article/magic-weapons-chinas-political-influenceactivities-under-xi-jinping; and Alex Joske, "The Party Speaks for You."

${ }^{13}$ William C. Hannas and Didi Kirsten Tatlow, Beyond Espionage: China's Quest for Foreign Technology (Routledge 1st edition, September 2020); Alex Joske, "Hunting the Phoenix" (Australian Strategic Policy Institute, 2020), https://www.aspi.org.au/report/hunting-phoenix.

${ }^{14}$ Kristine Lee and Alexander Sullivan, "People's Republic of the United Nations" (Center for a New American Security, May 2019), https://s3.amazonaws.com/files.cnas.org/documents/CNAS-Report-China-IOfinal-web-b.pdf?mtime=20190513092354.

${ }^{15}$ Receipts of local UFWD paying overseas scientists available at: "The distribution list of provincial-level projects for the introduction of foreign intelligence special funds at the provincial level in 2018” [2018 年省级引进国外 智利专项经费直项目分配明细表], https://web.archive.org/web/20201112190122/http://webcache.googleusercont ent.com/search?q=cache\%3AKAaZ3LpEe4oJ\%3Arst.hunan.gov.cn\%2Frst\%2Fx 
xgk\%2Ftzgg\%2F201802\%2F9516964\%2Ffiles\%2Fe1c7ddd51dda49f6b70a6 ad5ae9b0490.xls $+c d=3 \& h l=e n \& c t=c l n k \& g l=u s$.

${ }^{16}$ The relevant section of the expense report is titled "Special funding for the introduction of foreign knowledge” (引进国外智力专项经费). “2017 Human Resources Special Fund Performance Evaluation Index Score Sheet” [2017 年度 人力资源专项资金绩效评价指标评分表], https://perma.cc/EKN9-9T79.

17 "The distribution list of provincial-level projects for the introduction of foreign intelligence special funds at the provincial level in 2018” [2018 年省级引进国外 智利专项经费直项目分配明细表], https://perma.cc/VK4P-GBV5; Toshi Yoshihara and Jack Bianchi, “Uncovering China's Influence in Europe: How Friendship Groups Co-opt European Elites" (Center for Strategic and Budgetary Assessments, 2020), https://csbaonline.org/uploads/documents/CSBA8225_(Uncovering_Chinas_Influ ence_Report)_FINAL.pdf.

18 "2017 Human Resources Special Fund Performance Evaluation Index Score Sheet” [2017 年度人力资源专项资金绩效评价指标评分表].

19 “Recommended Projects for Service Operations for Science and Technology Diplomats in 2014" [科技外交官服务行动推荐项目], https://web.archive.org/web/20201113210235/http://webcache.googleusercont ent.com/search?q=cache\%3AL2NAURzERW4J\%3Awww.pqldh.com\%2Fupload file\%2F2015\%2F0715\%2F20150715055302208.doc $+\& c d=5 \& h l=e n \& c t=c l n k \&$ $\mathrm{gl}=\mathrm{us}$.

20 "Recommended Projects for Service Operations for Science and Technology Diplomats in 2014" [科技外交官服务行动推荐项目], https://web.archive.org/web/20201113210235/http://webcache.googleusercont ent.com/search?q=cache\%3AL2NAURzERW4J\%3Awww.pqldh.com\%2Fupload file\%2F2015\%2F0715\%2F20150715055302208.doc +\&cd=5\&hl=en\&ct=clnk\& gl=us.

21 “Science and Technology Diplomat Service Activities" [科技外交官服务活动], China Association for International Science and Technology Cooperation [中国国 际科学技术合作协会], 2017, https://web.archive.org/web/20180830220010/http://caistc.com/templets/caistc/ images/2017jijin.pdf; "2019 US China Innovation and Investment Summit," US China Innovation Alliance, May 2019,

https://web.archive.org/web/20210121195119/https://ucis2019.uschinainnovati on.org/page-1921.

22 “Sino-Italian Technology Transfer Center" [中意技术转移中心], https://web.archive.org/web/20200920141759/https://cittc.org.cn/news/top/5.ht $\underline{\mathrm{ml}}$. 
${ }^{23}$ Ngor Luong, Zachary Arnold, and Ben Murphy, "Understanding Chinese Government Guidance Funds" (Center for Security and Emerging Technology, March 2021), https://cset.georgetown.edu/research/understanding-chinesegovernment-guidance-funds/.

${ }^{24}$ The term used here is “境外," which the authors have interpreted to mean anything outside of China, both foreigners and overseas Chinese. Original CSET Translation of "Law of the People's Republic of China on Promoting the Conversion of Scientific and Technological Achievements" [中华人民共和国促进 科技成果转化法], National People's Congress (NPC; 全国人民代表大会; 全国人大) website, November 10, 2015.

${ }^{25}$ Original CSET Translation of "Notice of the Chinese Academy of Sciences on the Publication of the 'Project Management Measures for the Chinese Academy of Sciences Key Project for Transfer and Conversion of Scientific and Technological Achievements"” [中国科学院关于印发《中国科学院科技成果转移 转化重点专项项目管理办法》的通知], General Department (办公厅) of the Chinese Academy of Sciences (CAS; 中国科学院; 中科院), November 15, 2016.

${ }^{26}$ We sorted each project into one of eleven categories based on the names and full text descriptions of the reports that Chinese S\&T diplomats had filed.

Recognizing that labeling is subjective, two of the authors independently coded 100 of the 642 S\&T project reports, and agreed on the same technology label in 67 percent of cases. Each read and coded half of all PRC diplomat reports used in this study.

${ }^{27}$ Karen M. Sutter, "'Made in China 2025' Industrial Policies: Issues for Congress," Congressional Research Service, August 2020, https://fas.org/sgp/crs/row/IF10964.pdf.

${ }^{28}$ Tai Ming Cheung et al., "Planning for Innovation: Understanding China's Plans for Technological, Energy, Industrial, and Defense Development."

${ }^{29}$ Sutter, “'Made in China 2025' Industrial Policies."

30 "The National Medium- and Long-Term Program for Science and Technology Development (2006-2020): An Outline," PRC State Council, 2006, https://www.itu.int/en/ITUD/Cybersecurity/Documents/National_Strategies_Repository/China_2006.pdf.

${ }^{31}$ Elsa Kania, Ngor Luong, Caroline Meinhardt, Ben Murphy, Dahlia Peterson, Helen Toner, Graham Webster, Emily Weinstein, Translation of "Guiding Opinions on Expanding Investment in Strategic Emerging Industries and Cultivating Strengthened New Growth Points and Growth Poles," New America, September 2020, https://www.newamerica.org/cybersecurityinitiative/digichina/blog/new-chinese-ambitions-strategic-emerging-industriestranslated/. 
${ }^{32}$ William Hannas, Huey-Meei Chang, Catherine Aiken, Daniel Chou, "China AlBrain Research: Brain-Inspired Al, Connectomics, Brain-Computer Interfaces" (Center for Security and Emerging Technology, September 2020), https://cset.georgetown.edu/research/china-ai-brain-research/.

33 “Greek pharmaceutical company seeks Chinese partners and marketers" [希腊 制药公司寻求中国合作伙伴和营销商], Science and Technology Diplomats Service Operations Topics [科技外交官服务行动专题], 2015, https://perma.cc/X3XMWJM5; and Chinese Delegation Visit in Uni-Pharma premises," Uni-Pharma, May 24, 2018, https://perma.cc/WJ5G-TDVF.

34 “DryLet Microbial decontamination" [DryLet 微生物除污], Science and Technology Diplomats Service Operations Topics [科技外交官服务行动专题], 2016, https://perma.cc/ZF46-QJ5J.

35 "Strategic relationship with Chinese PPP leader opens PRC market to DryLet," DryLet, November 2017, https://www.drylet.com/hoyo-drylet-partnership/.

36 “Ventilator auxiliary treatment equipment" [呼吸机辅助治疗设备], Science and Technology Diplomats Service Operations Topics [科技外交官服务行动专题], 2020, https://perma.cc/RUX4-GWNC.

${ }^{37}$ Dean Koh, "Hospitech Respiration starts joint venture with AwakeZone to expand reach in China," MobiHealthNews, November 10, 2020, https://www.mobihealthnews.com/news/asia-pacific/hospitech-respirationstarts-joint-venture-awakezone-expand-reach-china; and Jerusalem Post Staff, "Israeli medical device company announces new joint venture with China," The Jerusalem Post, November 5, 2020, https://www.jpost.com/healthscience/israeli-medical-device-company-announces-new-joint-venture-withchina-648125.

${ }^{38}$ Keywords used: 算法, 自动, 自主性, 自治, 控制论, 完全自主, 人类代理组队, 人为 控制, 人在半实物, $\mathrm{Al}$, 智能, 人机, 人体上的环, 人类外的的环, 无人, 预测, 人工智能, 计算机视觉, 深度学习, 机器人.

39 "Senstone Inc.," Crunchbase, accessed March 2021, https://www.crunchbase.com/organization/senstone.

${ }^{40}$ Nazar Fedorchuk, "Manufacturing: 'Hiccups' and Things to Watch Out For," Linkedln, September 10, 2019, https://www.linkedin.com/pulse/manufacturinghiccups-things-watch-out-nazar-fedorchuk.

41 “Leuven Instruments Semiconductor Equipment Project, Belgium” [比利时鲁汶 仪器半导体装备项目], Science and Technology Diplomats Service Operations Topics [科技外交官服务行动专题], 2016, https://perma.cc/9FCV-3B9T.

42 “Leuven Instruments" [鲁汶仪器], https://perma.cc/86E8-3MLE. 
43 “Dr. Kaidong Xu," Semicon China, https://archive.vn/V32xk.

44 “About," Innoviz Technologies, https://innoviz.tech/about.

${ }^{45}$ Elsa Kania et al., "New Chinese Ambitions for 'Strategic Emerging Industries,'

Translated," New America, October 2020,

https://www.newamerica.org/cybersecurity-initiative/digichina/blog/new-

chinese-ambitions-strategic-emerging-industries-translated/.

46 “Automotive Lidar Technology” [汽车激光雷达技术], Science and Technology Diplomats Service Operations Topics [科技外交官服务行动专题], 2019, https://perma.cc/5Y3A-XVWK.

47 "Innoviz Technologies Selected by Shaanxi Heavy Duty Automobile Co. for Autonomous Truck Project at Chinese Port," Innoviz Technologies via PR Newswire, February 12, 2020, https://www.prnewswire.com/newsreleases/innoviz-technologies-selected-by-shaanxi-heavy-duty-automobile-cofor-autonomous-truck-project-at-chinese-port-301003267.html.

48 "Rescue aircraft" [救援飞行机], Science and Technology Diplomats Service Operations Topics [科技外交官服务行动专题], 2019, https://perma.cc/P9YHgUPR.

49 "Aerostar Tactical Unmanned Aerial Vehicle," Airforce Technology, https://www.airforce-technology.com/projects/aerostaruav/; "Dutch to Rent Israeli UAVs for Afghanistan," Defense Industry Daily, March 25, 2009, https://www.defenseindustrydaily.com/Dutch-to-Rent-Israeli-UAVs-forAfghanistan-05254/; Abigail Klein Leichman, "Mexico buys advanced Israeli unmanned aerial system," ISRAEL21c, September 27, 2017, https://www.israel21c.org/mexico-buys-advanced-israeli-unmanned-aerialsystem/; and Office of the Secretary of Defense, "Unmanned Aircraft Systems Roadmap," U.S. Department of Defense (Washington, D.C.: Department of Defense, 2005), 65, https://fas.org/irp/program/collect/uav_roadmap2005.pdf.

${ }^{50}$ The Georgia Institute of Technology is the primary developer of the ARTEMIS software. See "ARTEMIS: Measuring Usability in a Virtual Environment_OnDemand Session," National Institute of Standards and Technology, June 8, 2020, https://www.nist.gov/video/artemis-measuring-usability-virtual-environmentondemand-session.

51 “Cloud-based computer software tool ARTEMIS" [基于云技术的计算机软件工 具 ARTEMIS], Science and Technology Diplomats Service Operations Topics [科 技外交官服务行动专题], 2018, https://perma.cc/9YRC-DEKT. In 2020, the Cobb County and Georgia Tech police departments participated in experiments using the ARTEMIS software. See "Augmented Reality Testing of Equipment and Multiple Immersive Simulations (ARTEMIS)," National Institute of Standards and Technology, November 24, 2020, https://www.nist.gov/ctl/pscr/funding- 
opportunities/past-funding-opportunities/psiap-user-interface/ar-testingequipment.

52 “Polarized video system for coastal waters monitoring” [用于沿海水域监测的偏 光视频系统], Science and Technology Diplomats Service Operations Topics [科技 外交官服务行动专题], 2020, https://perma.cc/8ZGR-QEGD.

${ }^{53}$ Eytan Halon, "Rafael, Stolero offer \$231m for Israeli drone maker Aeronautics," The Jerusalem Post, January 13, 2019, https://www.jpost.com/israel-news/rafael-stolero-offer-231m-for-israeli-dronemaker-aeronautics-577181.

54 "Polarized video system for coastal waters monitoring," Institute of Pacific Oceanography, Russian Academy of Sciences, November 2020.

${ }^{55}$ Chinese S\&T diplomats targeted technology projects within the following NATO members and Major Non-NATO Allies (MNNAs) of the United States: Australia, Belgium, Bulgaria, Canada, the Czech Republic, Denmark, France, Greece, Hungary, Israel, Italy, Japan, New Zealand, Norway, Poland, Romania, South Korea, Spain, and the United Kingdom. MNNAs are designated by the U.S. State Department; see Bureau of Political-Military Affairs, "Major Non-NATO Ally Status," U.S. Department of State, January 20, 2021, https://www.state.gov/major-non-nato-ally-status/.

${ }^{56}$ The Houston Consulate referred 69 of the 77 U.S.-based technology projects in our dataset. The remaining eight projects were referred by the PRC consulates in Chicago (2) and New York (2) or were not specified (4).

${ }^{57}$ From 2015 to 2020, Chinese S\&T diplomats targeted 25 projects related to information technology in the United States.

58 "2019 US China Innovation and Investment Summit," US China Innovation Alliance, May 2019, https://web.archive.org/web/20210121195119/https://ucis2019.uschinainnovati on.org/page-1921; Lydia DePillis, "Houston's tech scene looks to China for the capital it's been lacking," The Houston Chronicle, May 20, 2016, https://www.houstonchronicle.com/business/article/Houston-tech-scene-looksto-China-for-the-capital-7887908.php.

59 “Virtual reality therapy product 'Luminopia One' for treating children with amblyopia” [治疗儿童弱视的虚拟现实疗法产品 “Luminopia One”], Science and Technology Diplomats Service Operations Topics [科技外交官服务行动专题], April 8, 2021, https://perma.cc/EK8B-BGJ8.

${ }^{60}$ Government-sponsored laboratories home to more than one PRC-identified "cooperation opportunity" included the Russian Academy of Sciences (40), Korea Electronics and Telecommunications Research Institute (6), Russian Central Academy of Robotics and Cybernetics (3), Romanian National Electrical 
Engineering Research Institute (2), VTT Technical Research Centre of Finland (2), Korea National Defense Science Research Institute (2), and Indonesian Institute of Science (2).

61 "Energy-saving motor project using soft magnetic composite materials" [使用 软磁复合材料的节能马达项目], Science and Technology Diplomats Service Operations Topics [科技外交官服务行动专题], 2015, https://perma.cc/SS8NEPGU.

62 “Drilling Technology, Dynamic Tubular Systems" [钻探技术

DynamicTubularSystems], Science and Technology Diplomats Service Operations Topics [科技外交官服务行动专题], 2016, https://perma.cc/UZC8LZLQ.

63 “Carmell Series C (financing)” [Carmell C 轮 (融资)], Science and Technology Diplomats Service Operations Topics [科技外交官服务行动专题], 2018, https://perma.cc/G57G-PB4Q.

${ }^{64}$ Lingling Wei and Bob Davis, "How China Systematically Pries Technology from U.S. Companies," The Wall Street Journal, September 26, 2018, https://www.wsj.com/articles/how-china-systematically-pries-technology-fromu-s-companies-1537972066.

65 "Brno International Medical Research Center in Czech Republic seeks Chinese partner institutions" [捷克布尔诺国际医疗研究中心寻求中方合作机构], Science and Technology Diplomats Service Operations Topics [科技外交官服务行动专题], 2016, https://perma.cc/D8HG-S2QS.

${ }^{66}$ We selected the 81 S\&T projects in our dataset that were hosted by companies and filed by PRC diplomats in 2015 and 2016, randomized them, and investigated the first 30 cases.

${ }^{67}$ Some companies entered into licensing deals with firms in China and attended Chinese diplomats' "matchmaking" events. In other cases, we found patents held by Chinese firms that cited prior patents held by the U.S. company.

68 “Notice of domestic sales start of PRD defect inspection 'FPIS'” [FPD 欠陥検査 システム「FPIS」国内販売開始のお知らせ], CyberNet, January 15, 2013, https://www.cybernet.jp/news/press/2012/20130115.html.

69 "Orbital Traction Completes SBIR, demonstrates efficiency improvements," Orbital Traction, November 10, 2020, http://orbitaltraction.com/orbital-tractioncompletes-sbir-demonstrates-efficiency-improvements/.

70 "Strategic relationship with Chinese PPP leader opens PRC market to DryLet," DryLet, November 9, 2017, https://www.drylet.com/hoyo-drylet-partnership/.

71 "Ecotech \& China: Working Towards a Clear Future," Ecotech, May 30, 2017, https://www.ecotech.com/ecotech-china-working-towards-a-clear-future/. 
72 "BioGenerator company MediBeacon enters into commercialization partnership with Huadong Medicine," BioGenerator, July 2019, https://biogenerator.org/news/biogenerator-company-medibeacon-enters-into30m-investment-and-commercialization-partnership-with-huadong-medicine/.

73 "Guozhen Environmental to acquire 100\% interest in Norway's Goodtech Environment AS," ChinaGoAbroad, October 16, 2015, http://www.chinagoabroad.com/en/recent_transaction/guozhen-environmentalto-acquire-100-interest-in-norway-s-goodtech-environment-as.

74 "Exhibiting at CPhl China," RotaChrom, June 22, 2019, https://rotachrom.com/exhibiting-at-cphi-chinal.

75 "Yiawei Yao," Linkedln, accessed March 2020, https://www.linkedin.com/in/jiawei-yao-90a379a9/?originalSubdomain=cn.

76 "RCVF announce their first investment to support the Russian substrate producer Rusalox," Russia-China Investment Fund, June 6, 2019, https://rdif.ru/Eng_fullNews/4098/.

77 "GREENCOMM CO., LTD.," 10times, December 2016, https://10times.com/company/greencomm-co-ltd.

${ }^{78}$ Fearghal O'Connor, "Irish eco firm Butterfly Cups believes it can solve the world's disposable cup problem," The Independent, February 17, 2019, https://www.independent.ie/business/irish/irish-eco-firm-butterfly-cupsbelieves-it-can-solve-the-worlds-disposable-cup-problem-37823289.html.

79 “Partners," China Israel Jizhi Technology Co., Ltd., 2018, http://www.chinaisraeljizhi.com/en/product/ajis63c/.

${ }^{80}$ Vanessa Gu and Alok Gupta, "China's Nanhu Lake sees clear waters for first time in 12 years," CGTN, July 9, 2020, https://news.cgtn.com/news/2020-0709/China-s-Nanhu-Lake-sees-clear-waters-for-first-time-in-12-years-RZfHZw26LS/index.html.

81 "Pickup trucks, Vans and Land Rover Style Vehicles," ThinkDefence, accessed March 2021, https://www.thinkdefence.co.uk/light-strike-brigade/lightweightvehicles/.

82 Joy Wong, "Oberaigner Aerospace to Open Up New Market with New Airplane," China Aviation Daily, August 31, 2012, http://www.chinaaviationdaily.com/news/21/21128.html.

${ }^{83}$ CYBERNET Systems Corporation, accessed March 2021, https://www.cybernet.com/. 
84 "Noesis Solutions opens subsidiary in Shanghai to ramp up direct sales in China," Noesis Solutions, May 2, 2016, https://www.noesissolutions.com/aboutnoesis-solutions/news-events/noesis-solutions-opens-subsidiary-in-shanghaito-ramp-up-direct-sales-in-china.

85 "Cybernet Systems Co., Ltd." (Bridge Report, March 9, 2018), https://www.cybernet.jp/english/documents/pdf/ir/library/20174QAnalystReport s.pdf.

86 "Orbital Traction Completes SBIR, demonstrates efficiency improvements."

${ }^{87}$ Lydia DePillis, "Houston tech scene looks to China for the capital it's been lacking," The Houston Chronicle, May 20, 2016, https://www.houstonchronicle.com/business/article/Houston-tech-scene-looksto-China-for-the-capital-7887908.php.

88 "Annual Report," DENSO Corporation, 2015, http://densomedia-na.com/wpcontent/uploads/2015-Annual-Report.pdf.

${ }^{89}$ Alex Rubin, Alan Omar Loera Martinez, Jake Dow, and Anna Puglisi, “The Huawei Moment” (Center for Security and Emerging Technology, forthcoming).

90 "Zhengzhou High-tech Zone launches International Collaborative Innovation System” [郑州高新区启动 “国际协同创新体系” ], The Gaoxin Times [高新时报], October 2019,

https://web.archive.org/web/20210121195034/http://www.zzgx.gov.cn/u/cms/z zgx/202005/04055510tsch.pdf.

${ }^{91}$ Sun Degang and Wu Tongyu, "The Fourth Industrial Revolution and China's Science and Technology Diplomacy to Arab Countries” [第四次工业革命与中国对 阿拉伯国家的科技外交], West Asia and Africa Journal [西亚非洲], June 2020, https://web.archive.org/web/20210121230625/http://www.xyfzqk.org/UploadFil e/lssue/tddo3gaw.pdf.

92 In May 2015, MOST operated 70 S\&T directorates within PRC embassies and consulates in 43 countries. By the end of 2019, the number had grown to 80 directorates in 53 countries. See reports titled "Opportunities for international science and technology cooperation in the service of science and technology diplomats" [科技外交官服务行动国际科技合作机会], PRC Ministry of Science and Technology, 2015, https://perma.cc/5NEJ-Y5GL; and 2019, https://perma.cc/UQ3V-DE2X. 